Prepared for the U.S. Department of Energy

under Contract DE-AC05-76RL01830

\title{
Computational Fluid Dynamics Modeling of The Dalles Project: Effects of Spill Flow Distribution Between the Washington Shore and the Tailrace Spillwall
}

\section{Rakowski MC Richmond JA Serkowski}

2010 


\title{
DISCLAIMER
}

This report was prepared as an account of work sponsored by an agency of the United States Government. Neither the United States Government nor any agency thereof, nor Battelle Memorial Institute, nor any of their employees, makes any warranty, express or implied, or assumes any legal liability or responsibility for the accuracy, completeness, or usefulness of any information, apparatus, product, or process disclosed, or represents that its use would not infringe privately owned rights. Reference herein to any specific commercial product, process, or service by trade name, trademark, manufacturer, or otherwise does not necessarily constitute or imply its endorsement, recommendation, or favoring by the United States Government or any agency thereof, or Battelle Memorial Institute. The views and opinions of authors expressed herein do not necessarily state or reflect those of the United States Government or any agency thereof.

\author{
PACIFIC NORTHWEST NATIONAL LABORATORY \\ operated by \\ BATTELLE \\ for the \\ UNITED STATES DEPARTMENT OF ENERGY \\ under Contract DE-AC05-76RL01830
}

Printed in the United States of America
Available to DOE and DOE contractors from the Office of Scientific and Technical Information,
P.O. Box 62, Oak Ridge, TN 37831-0062;
ph: (865) 576-8401
fax: $(865) 576-5728$
email: reports@adonis.osti.gov

\footnotetext{
Available to the public from the National Technical Information Service, U.S. Department of Commerce, 5285 Port Royal Rd., Springfield, VA 22161 ph: (800) 553-6847 fax: $(703) 605-6900$ email: orders@ntis.fedworld.gov online ordering: http://www.ntis.gov/ordering.htm
}

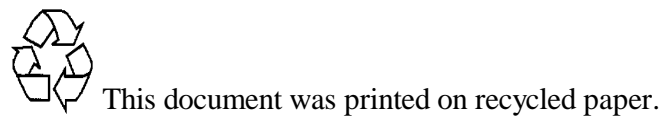




\section{Computational Fluid Dynamics Modeling of The Dalles Project: Effects of Spill Flow Distribution Between the Washington Shore and the Tailrace Spillwall}

CL Rakowski

JA Serkowski

MC Richmond

2010

Prepared for

the US Army Corps of Engineers, Portland District

Portland, OR 



\section{Summary}

The U.S. Army Corps of Engineers-Portland District (CENWP) has ongoing work to improve the survival of juvenile salmonids (smolt) migrating past The Dalles Dam. As part of that effort, a spillwall was constructed to improve juvenile egress through the tailrace downstream of the stilling basin. The spillwall was designed to improve smolt survival by decreasing smolt retention time in the spillway tailrace and the exposure to predators on the spillway shelf. The spillwall guides spillway flows, and hence smolt, more quickly into the thalweg.

In this study, an existing computational fluid dynamics (CFD) model was modified and used to characterize tailrace hydraulics between the new spillwall and the Washington shore for six different total river flows. The effect of spillway flow distribution was simulated for three spill patterns at the lowest total river flow. The commercial CFD solver, STAR-CD version 4.1, (CD-adapco, Computational Dynamics Limited 2009) was used to solve the unsteady Reynoldsaveraged Navier-Stokes equations together with the $\mathrm{k}-\varepsilon$ turbulence model. Free surface motion was simulated using the volume-of-fluid (VOF) technique.

The model results were used in two ways. First, results graphics were provided to CENWP and regional fisheries agency representatives for use and comparison to the same flow conditions at a reduced-scale physical model. The CFD results were very similar in flow pattern to that produced by the reduced-scale physical model but these graphics provided a quantitative view of velocity distribution. During the physical model work, an additional spill pattern was tested. Subsequently, that spill pattern was also simulated in the numerical model.

The CFD streamlines showed that the hydraulic conditions were likely to be beneficial to juvenile fish egress at the higher total river flows (120 kcfs and greater, uniform flow distribution). At the lowest flow case, $90 \mathrm{kcfs}$, it was necessary to use a non-uniform distribution. Of the three distributions tested, splitting the flow evenly between Bay 7 and Bay 8 was deemed most beneficial for egress by CENWP fisheries biologists and regional fishery agency representatives. The numerical and physical model results were very similar, building confidence in both hydraulic tools. 



\section{Acknowledgments}

Financial support for this study was provided by the U.S. Army Corps of Engineers under MIPR W66QKZ92453394. The authors would like to thank Laurie Ebner, U.S. Army Corps of Engineers, Portland District, for the discussions, support, and insight that improved this study. The authors would like to thank Lyle Hibler (PNNL) for his careful technical review. His role in the preparation of this document were appreciated and improved the final product. 



\section{Abbreviations and Acronyms}

$\begin{array}{ll}\text { ABBREV } & \text { DEFINITION } \\ \text { 2D } & \text { two dimensional } \\ \text { 3D } & \text { three dimensional } \\ \text { ADCP } & \text { acoustic Doppler current profiler } \\ \text { CAD } & \text { Computer-aided design } \\ \text { CENWP } & \text { U.S. Army Corps of Engineers, Portland District } \\ \text { CFD } & \text { computational fluid dynamics } \\ \text { DGAS } & \text { Dissolved Gas Abatement Study } \\ \text { ERDC } & \text { Engineer Research and Development Center, Vicksburg, MS } \\ \text { FPP } & \text { Fish Passage Plan } \\ \text { GIS } & \text { Geographic Information System } \\ \text { HRIC } & \text { High resolution interface capturing } \\ \text { JDA } & \text { John Day Dam } \\ \text { kcfs } & \text { Thousand cubic feet per second } \\ \text { MASS2 } & \text { Modular Aquatic Simulation System in Two Dimensions } \\ \text { NAD83 } & \text { North American Datum of 1983 } \\ \text { NGVD29 } & \text { National Geodetic Vertical Datum of 1929 with the 1947 adjustment } \\ \text { MARS } & \text { monotone advection and reconstruction scheme } \\ \text { PNNL } & \text { Pacific Northwest National Laboratory } \\ \text { RM } & \text { River Mile } \\ \text { STL } & \text { stereolithography } \\ \text { TDA } & \text { The Dalles Dam } \\ \text { TR } & \text { Total River flow } \\ \text { TSW } & \text { Temporary Spillway Weir } \\ \text { USACE } & \text { U.S. Army Corps of Engineers } \\ \text { USGS } & \text { U.S. Geological Survey } \\ \text { UD } & \text { Upwind difference } \\ \text { VOF } & \text { volume of fluid } \\ & \end{array}$





\section{Contents}

Summary . . . . . . . . . . . . . . . . . . . . . iii

Acknowledgments ........................ . . . . v

Abbreviations and Acronyms . . . . . . . . . . . . . . . . vii

1.0 Introduction . . . . . . . . . . . . . . . . . . . . . . . 1.1

2.0 Methods . . . . . . . . . . . . . . . . . . . . . . . . . . . . . . 2.1

2.1 Tailrace 3D CFD Model $\ldots \ldots \ldots \ldots \ldots \ldots$

2.2 Computational Model Domain . . . . . . . . . . . . . . . . 2.1

2.2 .1 Modification of Existing Model . . . . . . . . . . . . . . . . 2.1

2.2 .2 Confirmation of Model Truncation . . . . . . . . . . . . . . 2.2

2.2 .3 Low Flow Modifications . . . . . . . . . . . . . . . . . . . . 2.3

2.3 Tailrace Spillway Flow Scenarios . . . . . . . . . . . . . . . . . 2.4

2.4 Flow Visualization and Analysis . . . . . . . . . . . . . . . . . . . . . 2.4

3.0 Results and Discussion . . . . . . . . . . . . . . . . . . . . 3.1

3.1 Impacts of Model Truncation $\ldots \ldots \ldots \ldots \ldots . \ldots \ldots$

3.2 Flow Scenarios $\ldots \ldots \ldots \ldots \ldots . \ldots \ldots \ldots$

4.0 Conclusions . . . . . . . . . . . . . . . . . . . . . . . . . 4.1

5.0 References . . . . . . . . . . . . . . . . . . . . . . . . 5.1

Appendix A - Additional Graphics . . . . . . . . . . . . . . . . . . A.1 


\section{Figures}

1.1 Location of The Dalles Project and the Spillwall under Construction. Photo by Lindsey Gay, USACE-CENWP. . . . . . . . . . . . . . . . . . . . . . . 1.2

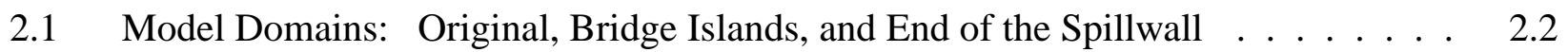

2.2 The Dalles Spillway, Spillwall, and Location of Bays _ . . . . . . . . . . . . . . 2.3

3.1 Comparison velocity results from the full river model and the truncated model for the area between the spillwall and the Washington shore. Total River was $150 \mathrm{kcfs}$ with $40 \%$ spill. The upper figure shows velocity vectors at an elevation of $69 \mathrm{ft}$, the lower figure at $72 \mathrm{ft}$.

3.2 Simulation results between the spillwall and the Washington shore for $120 \mathrm{kcfs}$ Total River, $40 \%$ spill at elevation $70 \mathrm{ft}$. The upper figure shows velocities at an elevation of $70 \mathrm{ft}$. The lower figure shows streamlines, colored by elevation, for par-

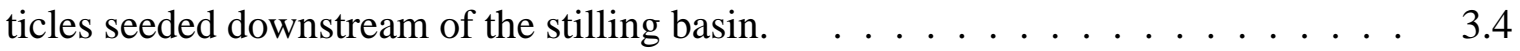

3.3 Simulated velocities near the Washington shore for $120 \mathrm{kcfs}$ Total River, $40 \%$ spill at elevation $70 \mathrm{ft}$. The lower figure shows areas with velocities greater $4 \mathrm{ft} / \mathrm{s}$ (a velocity believed to exclude predators) in red. . . . . . . . . . . . . 3.5

3.4 Simulation results between the spillwall and the Washington shore for $180 \mathrm{kcfs}$ Total River, $40 \%$ spill at elevation $70 \mathrm{ft}$. The upper figure shows velocities at an elevation of $70 \mathrm{ft}$. The lower figure shows streamlines, colored by elevation, for particles seeded downstream of the stilling basin. $\ldots \ldots \ldots \ldots$

3.5 Simulated velocities near the Washington shore for $180 \mathrm{kcfs}$ Total River, $40 \%$ spill at elevation $70 \mathrm{ft}$. The lower figure shows areas with velocities greater $4 \mathrm{ft} / \mathrm{s}$ (a velocity believed to exclude predators) in red. $\ldots \ldots \ldots \ldots . \ldots . \ldots . \ldots$

3.6 Simulation results between the spillwall and the Washington shore for $240 \mathrm{kcfs}$ Total River, $40 \%$ spill. The upper figure shows velocities at an elevation of $70 \mathrm{ft}$. The lower figure shows streamlines, colored by elevation, for particles seeded downstream of the stilling basin. $\ldots \ldots \ldots \ldots \ldots$

3.7 Simulated velocities near the Washington shore for $240 \mathrm{kcfs}$ Total River, $40 \%$ spill at elevation $70 \mathrm{ft}$. The lower figure shows areas with velocities greater $4 \mathrm{ft} / \mathrm{s}$ (a velocity believed to exclude predators) in red. . . . . . . . . . . . . . . 3.9

3.8 Simulation results between the spillwall and the Washington shore for $300 \mathrm{kcfs}$ Total River, $40 \%$ spill. The upper figure shows velocities at an elevation of $70 \mathrm{ft}$. The lower figure shows streamlines, colored by elevation, for particles seeded downstream of the stilling basin. 
3.9 Simulated velocities near the Washington shore for 300 kcfs Total River, $40 \%$ spill at elevation $70 \mathrm{ft}$. The lower figure shows areas with velocities greater $4 \mathrm{ft} / \mathrm{s}$ (a velocity believed to exclude predators) in red. . . . . . . . . . . . . 3.11

3.10 Simulation results between the spillwall and the Washington shore for $420 \mathrm{kcfs}$ Total River, $40 \%$ spill. The upper figure shows velocities at an elevation of $70 \mathrm{ft}$. The lower figure shows streamlines, colored by elevation, for particles seeded downstream of the stilling basin. $\ldots \ldots \ldots \ldots \ldots \ldots \ldots \ldots$

3.11 Simulated velocities near the Washington shore for $420 \mathrm{kcfs}$ Total River, $40 \%$ spill at elevation $70 \mathrm{ft}$. The lower figure shows areas with velocities greater $4 \mathrm{ft} / \mathrm{s}$ (a velocity believed to exclude predators) in red. . . . . . . . . . . . . . . . 3.13

3.12 Simulation results between the spillwall and the Washington shore for $90 \mathrm{kcfs}$ Total River, 40\% spill (Bays 1-6 at $6 \mathrm{kcfs}$ ). The upper figure shows velocities at an elevation of $70 \mathrm{ft}$. The lower figure shows streamlines, colored by elevation, for particles seeded downstream of the stilling basin. $\ldots \ldots \ldots . \ldots . . \ldots 3.14$

3.13 Simulated velocities near the Washington shore for 90 kcfs Total River $40 \%$ spill (Bays 1-6 at $6 \mathrm{kcfs}$ ), at elevation $70 \mathrm{ft}$. The lower figure shows areas with velocities greater $4 \mathrm{ft} / \mathrm{s}$ (a velocity believed to exclude predators) in red. $\ldots . . . .3 .15$

3.14 Simulation results between the spillwall and the Washington shore for $90 \mathrm{kcfs}$ Total River, 40\% spill (Bays 3-8 at $6 \mathrm{kcfs}$ ). The upper figure shows velocities at an elevation of $70 \mathrm{ft}$. The lower figure shows streamlines, colored by elevation, for particles seeded downstream of the stilling basin. $\ldots \ldots \ldots . \ldots . \ldots . . \ldots$

3.15 Simulated velocities near the Washington shore for 90 kcfs Total River $40 \%$ spill (Bays 3-8 at $6 \mathrm{kcfs}$ ), at elevation $70 \mathrm{ft}$. The lower figure shows areas with velocities greater $4 \mathrm{ft} / \mathrm{s}$ (a velocity believed to exclude predators) in red. $\quad . . . .3 .17$

3.16 Simulation results between near the Washington shore for $90 \mathrm{kcfs}$ Total River, $40 \%$ spill (Bays 7 and 8 at $18 \mathrm{kcfs}$ ), at elevation $70 \mathrm{ft}$. The lower figure shows streamlines, colored by elevation, seeded outside the stilling basin. . . . . . . . . 3.18

3.17 Simulated velocities near the Washington shore for 90 kcfs Total River $40 \%$ spill (Bays 7 and 8 at $18 \mathrm{kcfs}$ ), at elevation $70 \mathrm{ft}$. The lower figure shows areas with velocities greater $4 \mathrm{ft} / \mathrm{s}$ (a velocity believed to exclude predators) in red. $\quad . . .3 .19$

A.1 Iso-velocity surface for a velocity of $4 \mathrm{ft} / \mathrm{s}$ for lower flows. The upper figure shows 120 kcfs Total River. The lower figure shows $180 \mathrm{kcfs}$ Total River. . . . . . . . . . $\quad$ A.2

A.2 Iso-velocity surface for a velocity of $4 \mathrm{ft} / \mathrm{s}$ for higher flows. The upper figure shows $300 \mathrm{kcfs}$ Total River. The lower figure shows $420 \mathrm{kcfs}$ Total River. . . . . . . . . . A.3

A.3 Iso-velocity surface for a velocity of 12 and $16 \mathrm{ft} / \mathrm{s}$ for $420 \mathrm{kcfs}$ Total River. . . . . A.4 
A.4 Iso-velocity surface for a velocity of $30 \mathrm{ft} / \mathrm{s}$ for $420 \mathrm{kcf}$ Total Rivers. . . . . . . . . A.5

A.5 Iso-velocity surface for a velocity of $4 \mathrm{ft} / \mathrm{s}$ for $90 \mathrm{kcfs}$ Total River for Cases 1 and 2. The upper figure shows spill flows in Bays 1 to 6 . The lower figure shows spill flows in Bays 3 to $8 . \ldots \ldots \ldots \ldots$. . . . . . . . . . . . . . . .

A.6 Iso-velocity surface for a velocity of $4 \mathrm{ft} / \mathrm{s}$ for $90 \mathrm{kcfs}$ Total River for Case $3 \mathrm{with}$ spill flow in Bays 7 and $8 . . \ldots \ldots \ldots \ldots$ A.7 


\section{Tables}

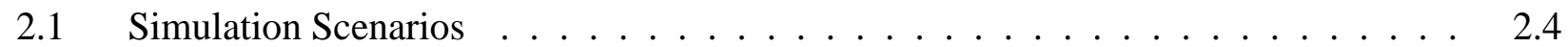





\subsection{Introduction}

The Dalles Project is a hydroelectric facility located at River Mile (RM) 191.5 on the Columbia River. Work is ongoing to improve the survival of juvenile salmonids (smolt) migrating past The Dalles Dam. As part of that effort, a spillwall was constructed to improve juvenile egress through the spillway downstream of the stilling basin. The spillwall was designed to improve smolt survival by decreasing smolt retention time in the spillway tailrace and the exposure to predators on the spillway shelf. The spillwall moves spillway flows, and hence smolt, more quickly into the thalweg.

In previous work, PNNL performed computational fluid dynamics (CFD) studies for The Dalles Dam tailrace (Figure 1.1) to assist US Army Corps of Engineers, Portland District (CENWP) in the siting and shape of a spillwall (Rakowski et al.2008). A three-dimensional (3D) unsteady CFD model including a free surface simulation using the volume-of-fluid (VOF) method was used to characterize and compare the hydraulics for the tailrace with and without the proposed wall for a suite of flow volumes. In 2009 and 2010, a spillwall was built between Bays 8 and 9, extending to the end of the shallow shelf.

The objectives of this study were to:

- modify the existing numerical model to include only the river inside the area between the spillwall and the Washington shore, and

- characterize the flow hydraulics resulting from a suite of flow volumes and for several spill patterns for a low flow case.

Previous observations from the prototype, physical model, and numerical models have shown hydraulic conditions adverse to safe smolt passage exist at The Dalles Dam when the spill flows are not evenly distributed between spilling bays and the spillwalls. However, at low flow volumes, biological criteria for minimum spillway gate opening would be violated for evenly distributed flows. The low flow simulations were used to explore spill discharge distribution options for creating the best possible egress conditions when limited flow was available for spill. 

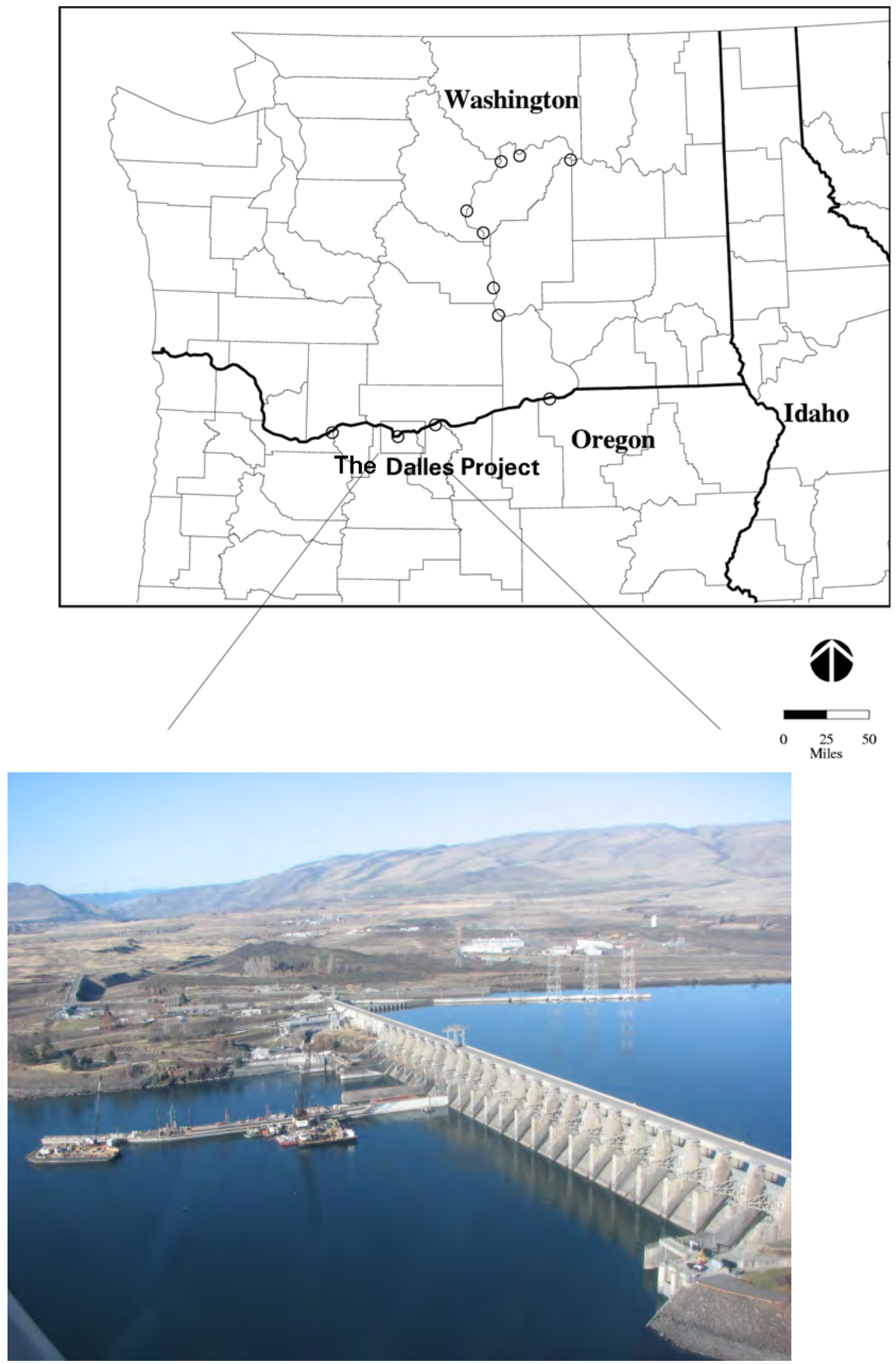

Figure 1.1. Location of The Dalles Project and the Spillwall under Construction. Photo by Lindsey Gay, USACE-CENWP. 


\subsection{Methods}

The area of primary interest for this study was limited to the zone between the newly constructed spillwall and the Washington shore. Although this area was included in the work described in Rakowski et al. (2008), to reduce the computer run times, it was desired to reduce the computational domain without significantly impacting the flow solution. The computational mesh used in Rakowski et al. (2008) was modified to removed the sections of the model that were not needed for this application. Only the portion of the model between the spillwall and the Washington shore was retained. The area of interest was near the stilling basin and along the spillwall. However, for the low spill cases, it was necessary to add back a section downstream of the thalweg to prevent recirculation into the model through the downstream boundary.

\subsection{Tailrace 3D CFD Model}

The CFD model (STAR-CD version 4, CD-adapco, Computational Dynamics Limited 2009) solved the unsteady Reynolds-averaged Navier-Stokes equations together with the k- $\varepsilon$ turbulence model. Free surface motion was simulated using the volume-of-fluid (VOF) technique. High Resolution Interface Capturing (HRIC) was used to sharpen the air / water interface. The unsteady simulations were computationally intensive; the simulations were carried out on midscale computer clusters at PNNL using 20-40 processors.

The original simulations for the siting of the spillwall (Rakowski et al. 2008) were run using STAR-CD version 4.02. At the time of this work, STAR-CD 4.08 was the current version. Between these two version, major changes had been made to the way STAR-CD implemented VOF simulations so that the code physics and many of the parameters had changed. This made it not possible to directly compare simulation results of the new and old models. However, we assessed the differences in simulated hydraulics resulting from the changes in the model parameters and the mesh truncation (Sections 2.2.2 and 3.1).

For all simulations, the downstream boundary was a hydrostatic boundary with a specified water surface elevation. For low flows, the water surface elevation was that of the downstream gage from the physical model. For higher flows, the simulations results of Rakowski et al. (2008) were used to specify average water surface elevation across the downstream boundary location. Inflows were specified as a velocity parallel to the spillway ogee face at an elevation well above the downstream water surface. Velocity was calculated from Bernouli's equation, and flow height calculated by dividing the spill bay flow volume by velocity and bay width.

\subsection{Computational Model Domain}

\subsubsection{Modification of Existing Model}

The original model (Rakowski et al. 2008) was reduced from $10.5 \mathrm{M}$ cells to $7.39 \mathrm{M}$ cells by limiting it to the area between the spillwall and the Washington shore (Figure 2.1). This model had its downstream extent at the end of the spillwall. While the overall plan view extent of the model was greatly reduced, a large proportion of the cells in the original model were in the nearspillway area for bays 1-8 (Figure 2.2) to provide a well-resolved flow solution in the stilling 
basin. The reduction in computational time was the result of not only reducing the overall number of cells, but also reducing the downstream extent of the model. This model extent reduced the amount of time needed to bring the model to a quasi-steady solution by limiting the length of the model and hence the "sloshing" period as waves propagate the length of the model domain. The computation mesh used in this study terminated at the downstream end of the spillwall for higher flows. This was reasonable because the area between the spillwall and the Washington shore provided a slight flow constriction and was a flow control for all but the low flow cases. However, when additional highly non-uniform spillway operations were specified, the end of the spillwall was not sufficiently far downstream and an intermediate version developed the terminated adjacent to the Bridge Islands (see Figure 2.1, Section 2.2.3).

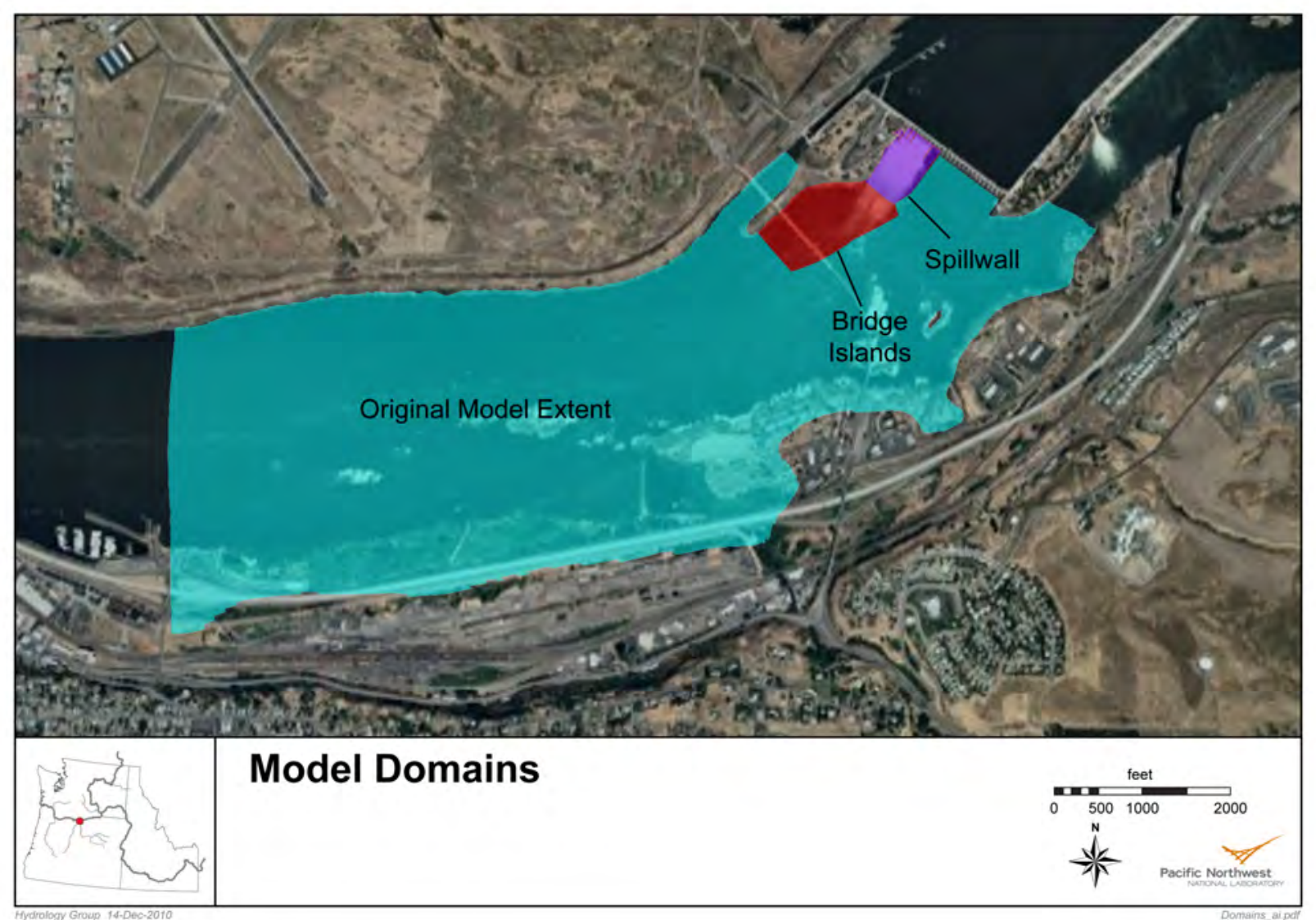

Figure 2.1. Model Domains: Original, Bridge Islands, and End of the Spillwall

\subsubsection{Confirmation of Model Truncation}

The full model was validated without a wall to field-measured velocity data. However, no validation data exist for the river with the constructed spillwall. To indirectly confirm that the truncated model was performing satisfactorily and the impacts of removing the model domain outside the spillwall, a case was run with the spillway flows of the $150 \mathrm{kcfs}$ case in Rakowski et al. (2008). There were two areas we expected simulations results between the old and new model to be different and one we expected them to be similar. In the stilling basin, we expected difference because the details of some of the model parameters changed with the new code ver- 


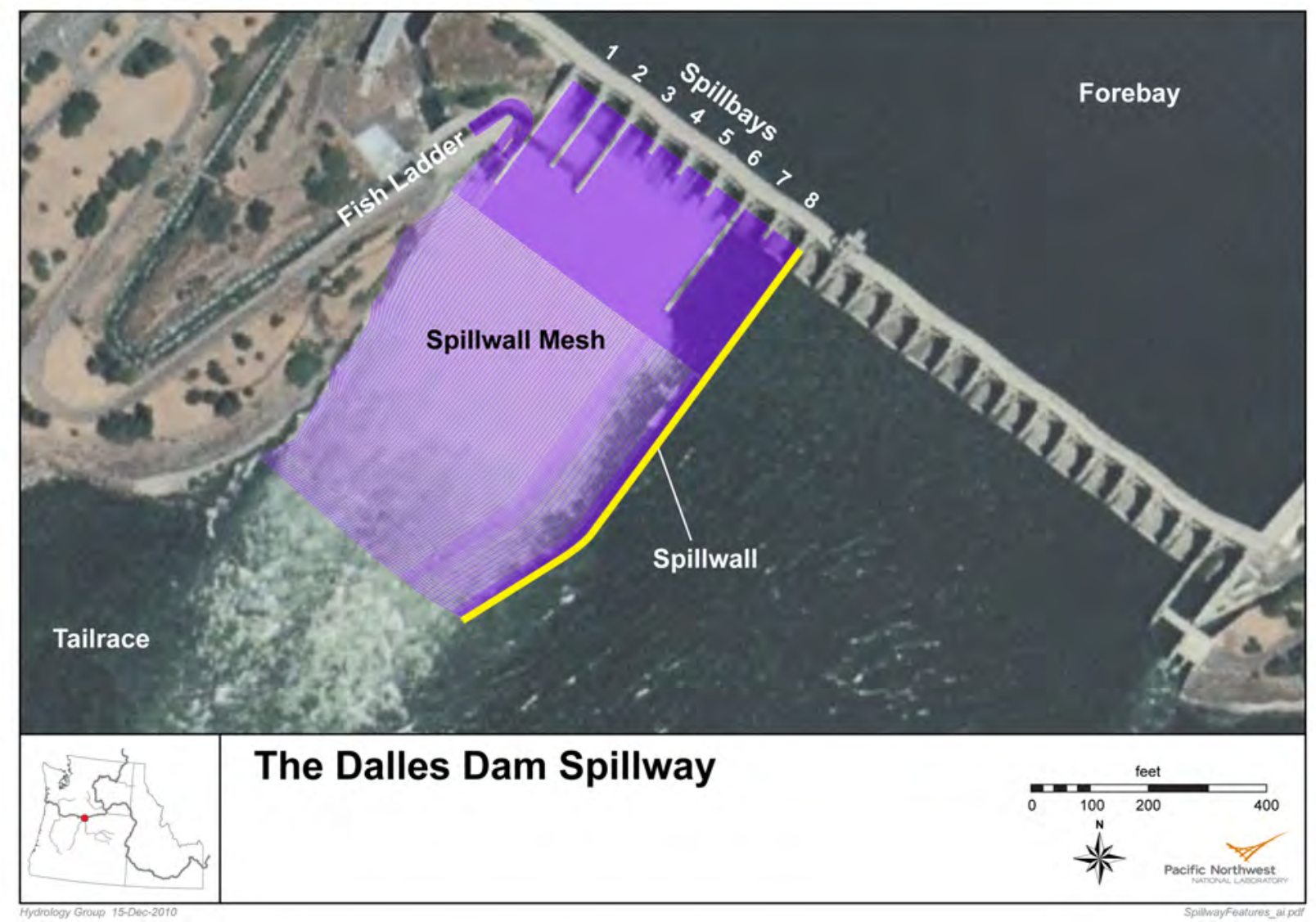

Figure 2.2. The Dalles Spillway, Spillwall, and Location of Bays

sion. In the new version of the code, we used upwind differencing which smooths the solution more than using MARS. In addition, the implementation of HRIC was slightly different. Differences were also expected at the downstream boundary of the shortened model because of the boundary location and a hydrostatic boundary being held to a constant elevation across the whole downstream boundary. In the validation, we looked for the velocities midway between the stilling basin and the end of the wall to be very similar.

\subsubsection{Low Flow Modifications}

When the lowest flow cases were run in that later portion of the study, it became obvious that a somewhat longer model was needed for certain spillway flow distributions. The area between the spillwall and Washington shore did not provide enough of a flow constriction to prevent recirculating flow at the downstream boundary for some spill flow distributions. In retrospect, it is obvious that one would expect a recirculation zone to form across the boundary location for the specified lower flow operations. Cells were added onto the model to increase distance to the downstream boundary. This model had $8.1 \mathrm{M}$ cells. Although the portion of the model associated with the powerhouse flows was removed, the lateral sweep of flow across the downstream end of the wall was modeled by specifying a velocity for the boundary for an elevation range of $-59 \mathrm{ft}$ to $74 \mathrm{ft}$. All scenarios run subsequent to finding the need for additional downstream cells 
were run using the longer model. However, the previously run models were not re-run. The details of which model was used with each scenario are detailed in Section 2.3.

\subsection{Tailrace Spillway Flow Scenarios}

From earlier work with the spill patterns for the wall built between Bays 6 and 7, it was known that, for the best egress conditions, it was necessary to have the flow evenly distributed between bays. For higher flows (120 - $420 \mathrm{kcfs}$ Total River with $40 \%$ spill), the spill would be evenly distributed between bays. At higher flows, additional bays would be opened. At low flows, however, it is not possible to have evenly distributed flow as so doing would violate the minimum gate opening specified as part of the biological criteria. Hence, at $90 \mathrm{kcfs}$ Total River, it is necessary to use a non-uniform spill distribution for the bays within the spillwall. The flows, spill volumes, and spill pattern used for the scenarios of this study are detailed in Table 2.1. The downstream extent of the model used is noted in Table 2.1 (see Figure 2.1 for location). When the need for extending the downstream boundary became apparent when running Case 3; all scenarios run after Case 3 used the longer computational domain.

Table 2.1. Simulation Scenarios

\begin{tabular}{lccccc}
\hline Case & $\begin{array}{c}\text { Total River } \\
(\mathrm{kcfs})\end{array}$ & $\begin{array}{c}\text { Spill } \\
(\mathrm{kcfs})\end{array}$ & $\begin{array}{c}\text { Pattern } \\
\text { Bays, opening }(\mathrm{ft})\end{array}$ & $\begin{array}{c}\text { Discharge per } \\
\text { Bay }(\mathrm{kcfs})\end{array}$ & $\begin{array}{c}\text { Downstream } \\
\text { Boundary }\end{array}$ \\
\hline Baseline 420 & 420 & 168 & $1-8 @ 14$ & 21 & Spillwall \\
Baseline 300 & 300 & 120 & $1-8 @ 10$ & 15 & Bridge Islands \\
Baseline 240 & 240 & 98 & $1-8 @ 8$ & 12 & Bridge Islands \\
Baseline 180 & 180 & 144 & $1-8 @ 6$ & 9 & Bridge Islands \\
Baseline 120 & 120 & 48 & $1-8 @ 4$, & 6 & Spillwall \\
Case 1 & 90 & 36 & $1-6 @ 4$, & 6 & Spillwall \\
Case 2 & 90 & 36 & $3-8 @ 4$, & 6 & Spillwall \\
Case 3 & 90 & 36 & $7-8 @ 12$, & 18 & Bridge Islands \\
\hline
\end{tabular}

\subsection{Flow Visualization and Analysis}

These model results were to be used, in part, in conjuntion with trips to the 1:80 reduced-scale physical model of The Dalles Project at ERDC in Vicksburg, MS. To make these model results accessible to engineers and fisheries biologists while at the physical model, graphics were created of plan view velocities at a single elevation, surface of iso-velocities, and streamlines were used to elucidate the flow patterns from the simulation results. These graphics were oriented on the spillway construction baseline. Positive comparisons of numerical and physical model results improve confidence in both tools. Visualizations of model results were provided to the CENWP and regional fisheries agency representatives prior to the trip to ERDC. Numerical model results for spill patterns developed while at ERCD (e.g., Case 3) are included in this report.

The velocity slice was taken at elevation $70 \mathrm{ft}$; streamlines were seeded just downstream of the stilling basin at an elevation of $70 \mathrm{ft}$. Results near the Washington shore and a vertical slice of velocity down the centerline of Bay 4 (for river flows greater than $90 \mathrm{kcfs}$ ) or between the fish 
ladder and Bay 1 (90 kcfs cases) were used. The vertical slices were thresholded at $20 \mathrm{ft} / \mathrm{s}$ and at $4 \mathrm{ft} / \mathrm{s}$. The latter velocity is believed to exclude predator fish.

Graphics of isovelocity surfaces were created for $4 \mathrm{ft} / \mathrm{s}$. For the $420 \mathrm{kcfs}$ runs, additional isovelocity plots for 12,16 , and $20 \mathrm{ft} / \mathrm{s}$ were created. These higher velocities have biological significance for adult migrants approaching the Washington shore fish ladder. 



\subsection{Results and Discussion}

\subsection{Impacts of Model Truncation}

In this study, a numerical model used in previous work was truncated and run with a newer version of the CFD solver code, STAR-CD. Even without any CFD code changes, we expected some differences in the flow solution. For this transient VOF simulation, the solution was expected to be very dynamic in and near the stilling basin, to have very similar velocities and water surface elevations across the flow domain adjacent to the bend of the spillwall, and to be somewhat different at the downstream boundary of the shorter model. The latter condition resulted from the water surface elevation being held constant across the whole boundary. There were no available field-measured velocities available as the spillwall was still under construction at the time these simulations were run, so no validation to field data was possible.

To assess the impact of truncating the model, we used results documented in Rakowski et al. (2008) for the $150 \mathrm{kcfs}, 40 \%$ spill case (Figure 3.1). For this study, the area that we wanted relative differences in the hydraulics were more near the stilling basin. Midway down the wall and across the channel, we expected the flow constriction provided by the wall to greatly reduce the impact of the spill pattern in all but the low-flow cases.

The modeled velocities are very similar between the spillwall bend and the Washington shore. These results indicate that the flows in the area upstream of the bend are not impacted by the boundary location. In consultation with CENWP, it was determined that the truncated model was appropriate for this study.

It was later found that for lower flows with an uneven flow distribution, it was necessary to move the downstream boundary further downstream. At the lower flows, recirculation developed across the downstream boundary location leading to model instabilities and unrealistic solutions. Hence, the flow boundary was moved further downstream for subsequent model runs.

\subsection{Flow Scenarios}

Streamlines, isovelocity surfaces, and contours of velocities were used to evaluate the simulated hydraulics between the spillwall and Washington shore. The isovelocity surface plots are in Appendix A.

In these flow scenarios, desired features included minimizing areas of recirculation, more uniform downstream velocities between the Washington shore and the spillwall, and velocities in excess of $4 \mathrm{ft} / \mathrm{s}$. These flow characterisitics are believed to enhance spillway survival by minimizing time spent in the stilling basin and tailrace and reducing exposure to predators.

Figures are grouped by the scenario. For each scenario, graphics in this section show:

- Velocity magnitude and vectors at an elevation of $70 \mathrm{ft}$. These show the over midelevation flow pattern. 


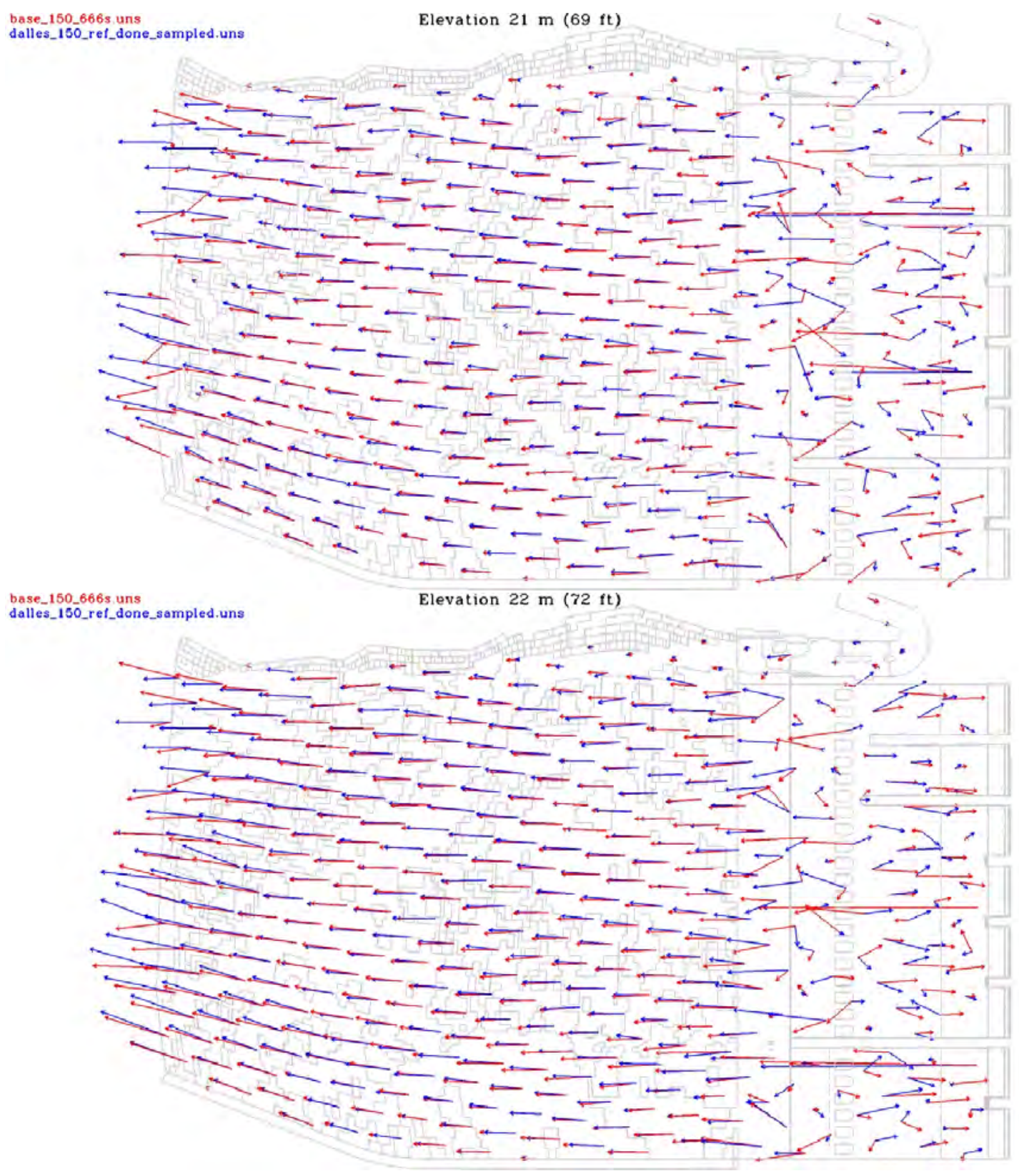

Figure 3.1. Comparison velocity results from the full river model and the truncated model for the area between the spillwall and the Washington shore. Total River was $150 \mathrm{kcfs}$ with $40 \%$ spill. The upper figure shows velocity vectors at an elevation of $69 \mathrm{ft}$, the lower figure at $72 \mathrm{ft}$. 
- Streamlines seeded at elevation $70 \mathrm{ft}$ downstream of the stilling basin (streamlines colored by elevation). These elucidate vertical components of flow.

- Vertical slice of velocity near the Washington shore and the fish ladder approach. These were to be used in conjunction with phyical model data in the characterization of nearshore hydraulics and flow characteristics encountered by upstream migrants on their way to the North Ladder.

- Vertical slice, as above, but with the velocity thresholded at $4 \mathrm{ft} / \mathrm{s}$.

For all baseline cases with a flat spill pattern (Figures 3.2 to 3.11), the model results show some recirculation downstream of the fish ladder, but that overall hydraulic conditions are good. Velocities across the flow domain are in excess of $4 \mathrm{ft} / \mathrm{s}$. For the lower flow scenarios $(90 \mathrm{kcfs}$ Total River with spill patterns), there are large areas of recirculation. For Case 1 (spill in Bays 1-6), a large recircultion zone developed between the end of the Bay 5/6 wall and the spillwall bend (Figure 3.12). For Case 2, a low velocity zone extended from the end of the short wall between Bays 2 and 3 across the end of the fish ladder entrance. In Case 3, the same volume of flow was concentrated in Bays 7 and 8. This spill pattern was first developed in the physical model. Most surprising to all observing at the physical model was how low the velocities were in the recirculation zone and that the flow expanded to fill the constriction at the downstream end of the spillwall. These observations were reproduced in the numerical model (Figures 3.16 and 3.17). 

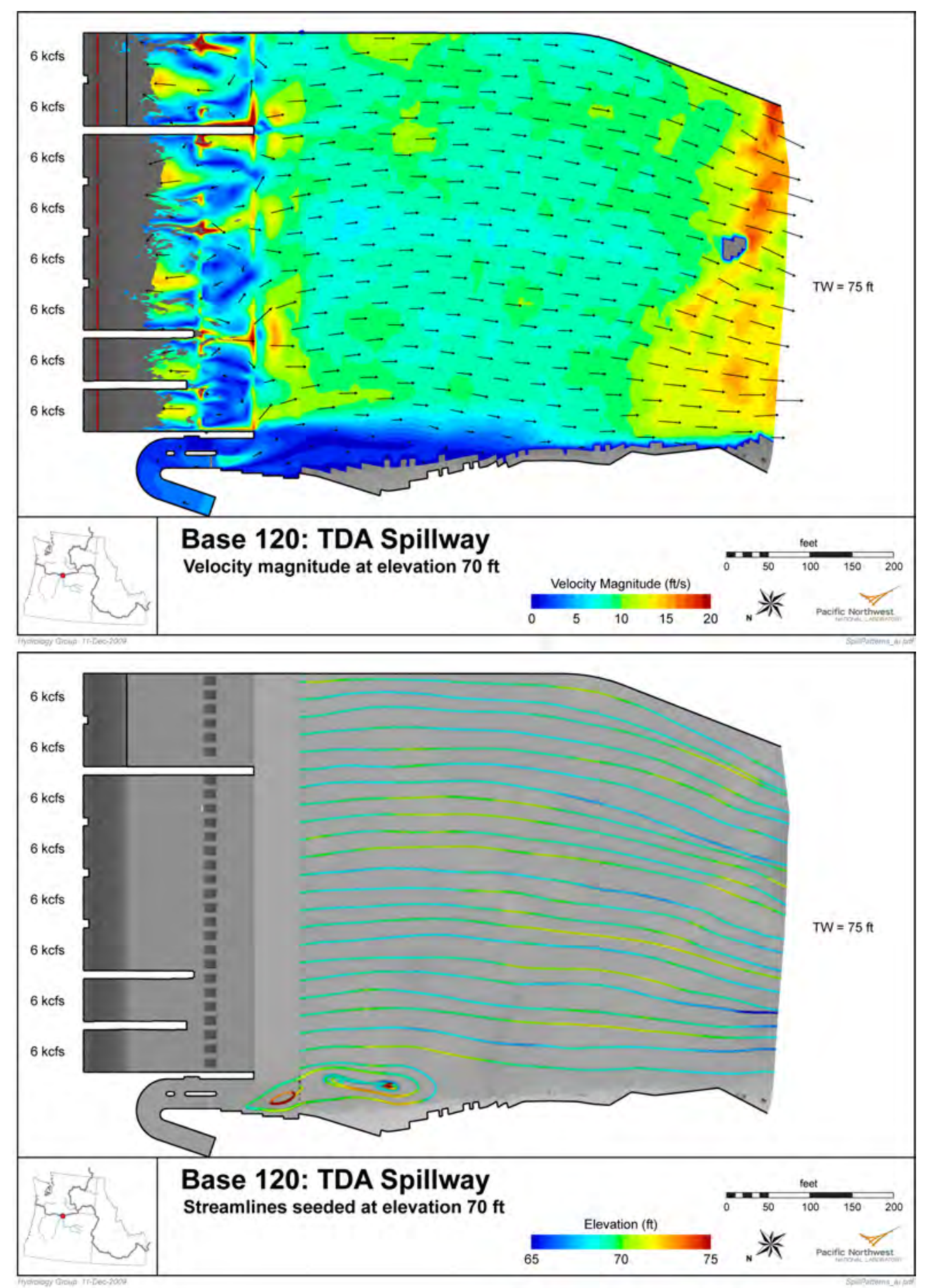

Figure 3.2. Simulation results between the spillwall and the Washington shore for $120 \mathrm{kcfs}$ Total River, $40 \%$ spill at elevation $70 \mathrm{ft}$. The upper figure shows velocities at an elevation of $70 \mathrm{ft}$. The lower figure shows streamlines, colored by elevation, for particles seeded downstream of the stilling basin. 

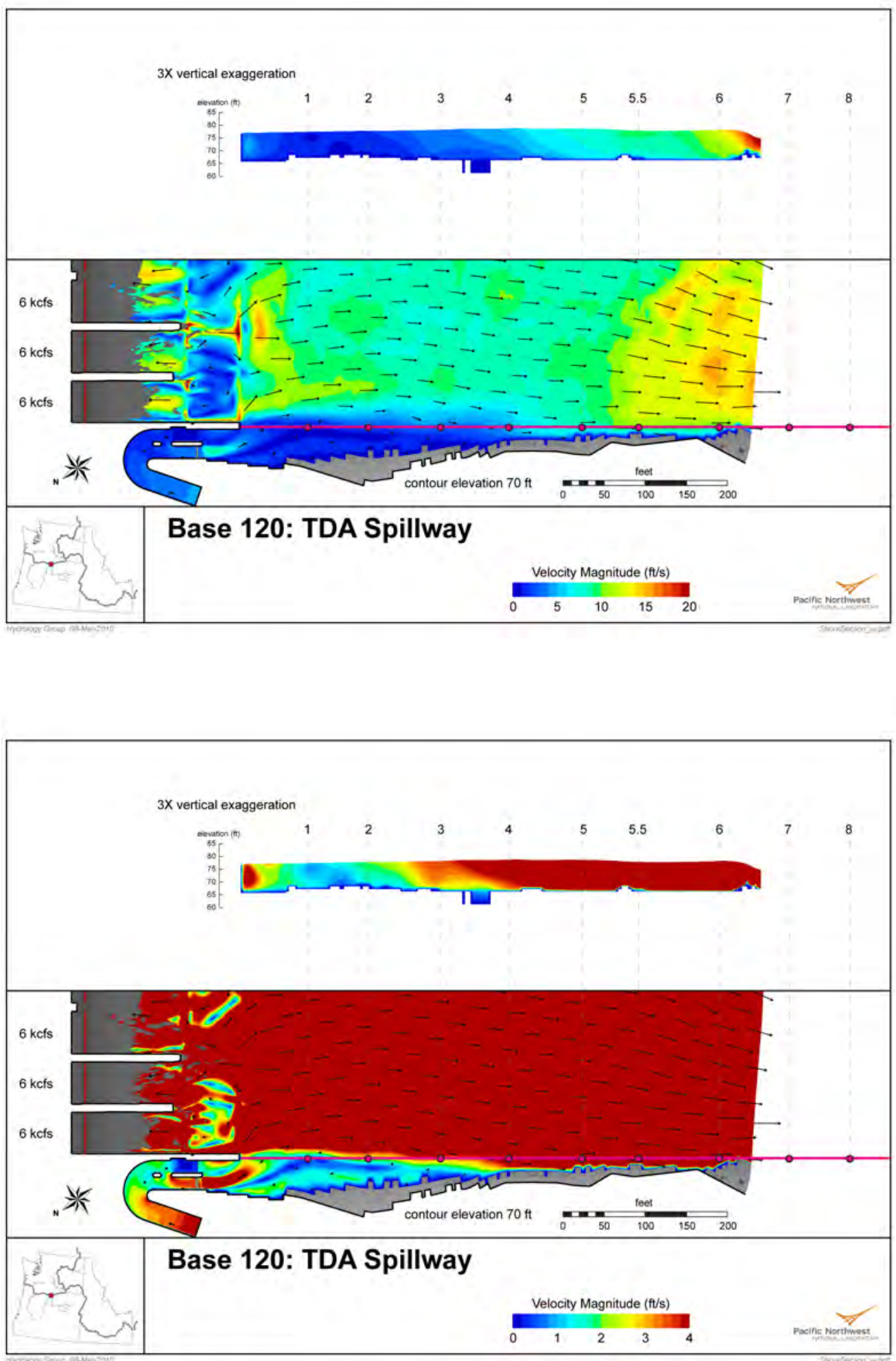

Figure 3.3. Simulated velocities near the Washington shore for $120 \mathrm{kcfs}$ Total River, $40 \%$ spill at elevation $70 \mathrm{ft}$. The lower figure shows areas with velocities greater $4 \mathrm{ft} / \mathrm{s}$ (a velocity believed to exclude predators) in red. 

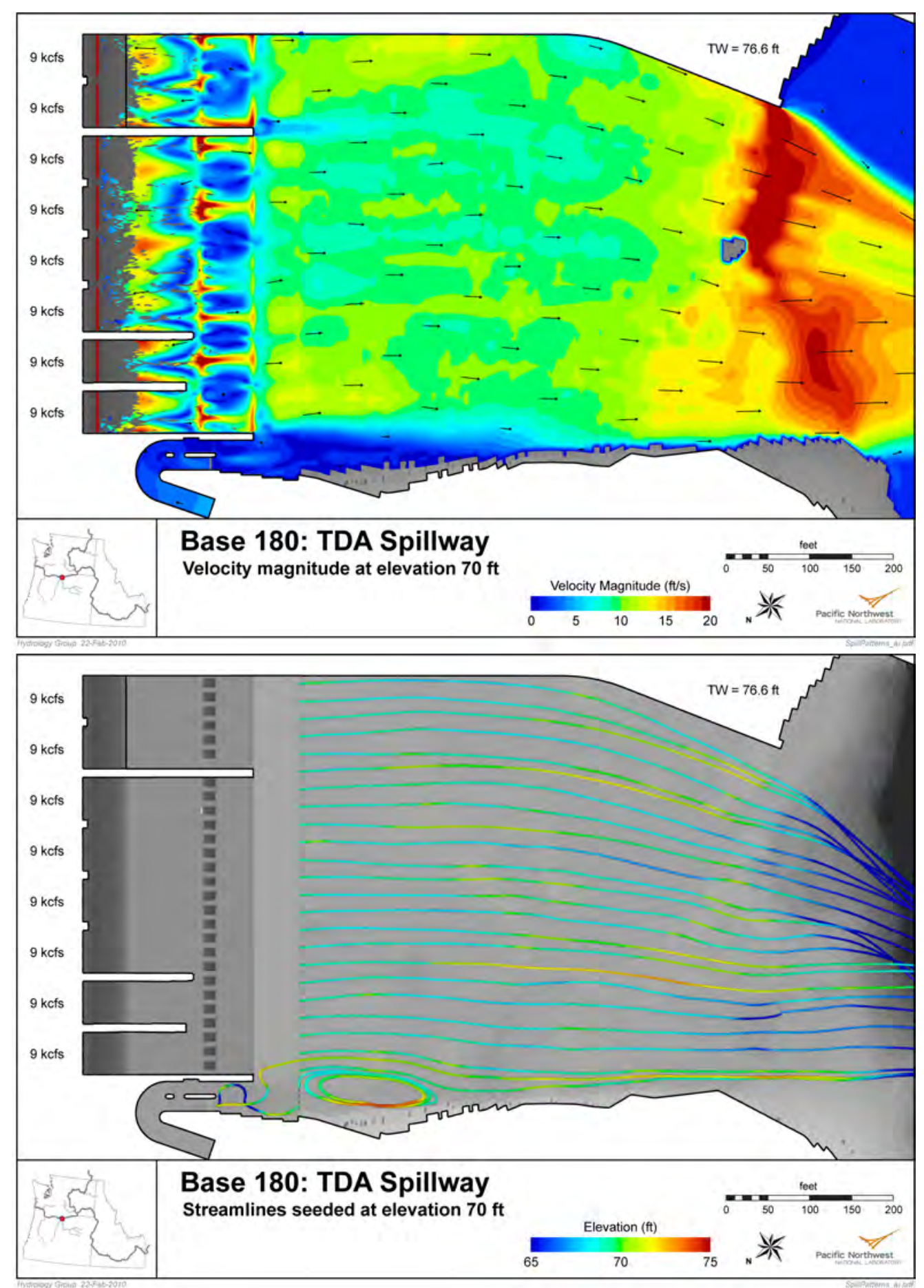

Figure 3.4. Simulation results between the spillwall and the Washington shore for $180 \mathrm{kcfs}$ Total River, $40 \%$ spill at elevation $70 \mathrm{ft}$. The upper figure shows velocities at an elevation of $70 \mathrm{ft}$. The lower figure shows streamlines, colored by elevation, for particles seeded downstream of the stilling basin. 

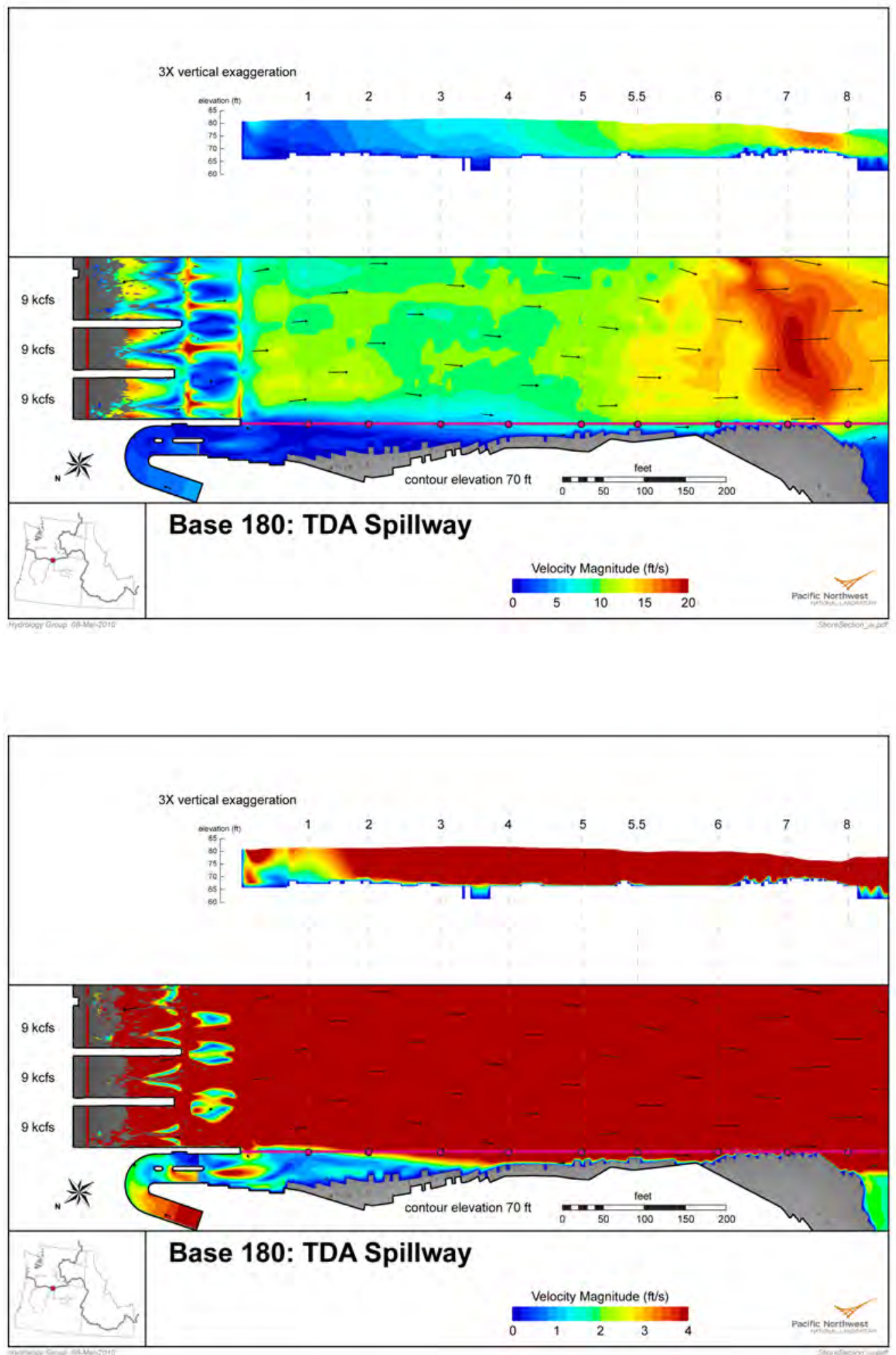

Figure 3.5. Simulated velocities near the Washington shore for $180 \mathrm{kcfs}$ Total River, $40 \%$ spill at elevation $70 \mathrm{ft}$. The lower figure shows areas with velocities greater $4 \mathrm{ft} / \mathrm{s}$ (a velocity believed to exclude predators) in red. 

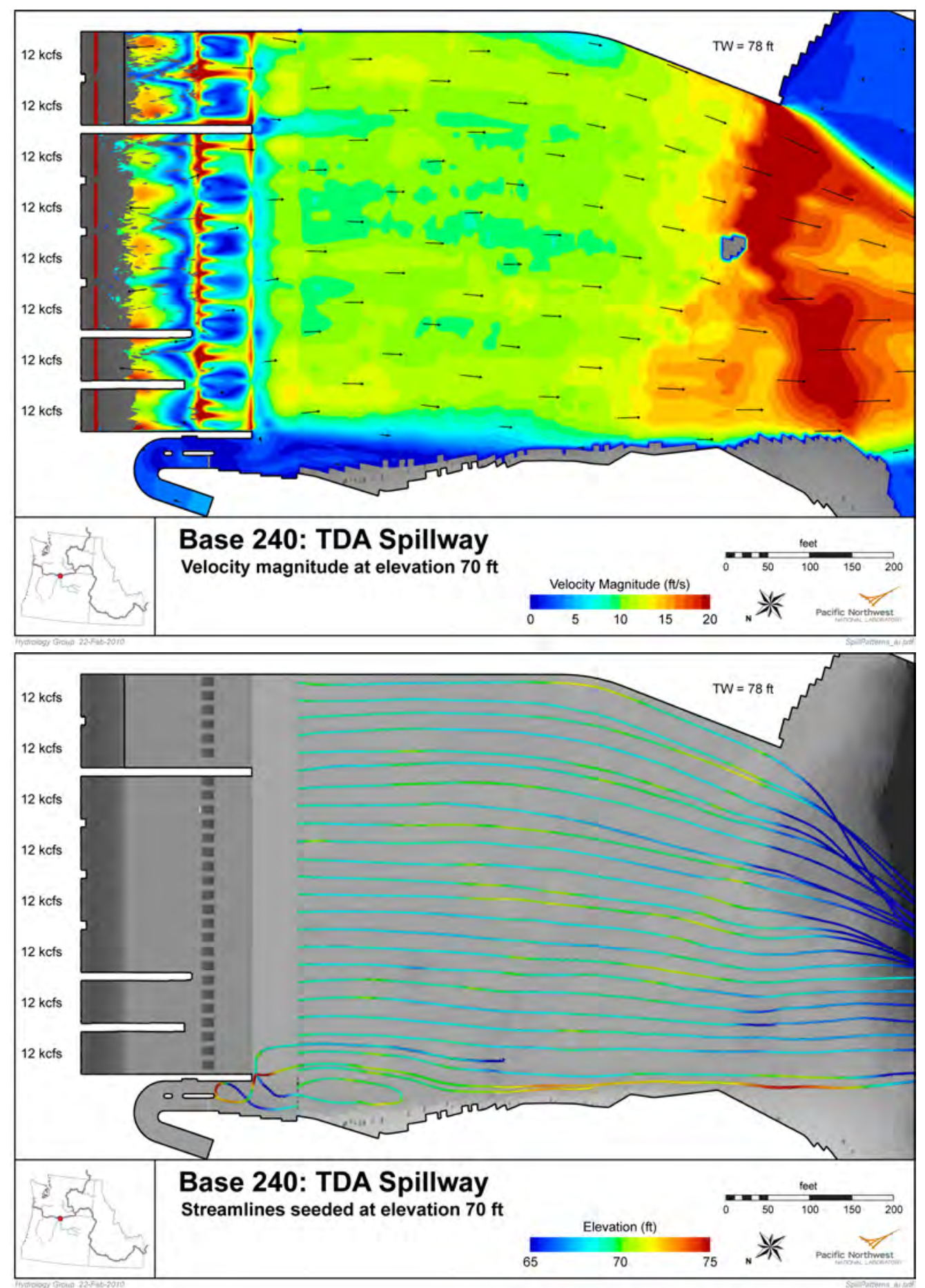

Figure 3.6. Simulation results between the spillwall and the Washington shore for $240 \mathrm{kcfs}$ Total River, $40 \%$ spill. The upper figure shows velocities at an elevation of 70 ft. The lower figure shows streamlines, colored by elevation, for particles seeded downstream of the stilling basin. 

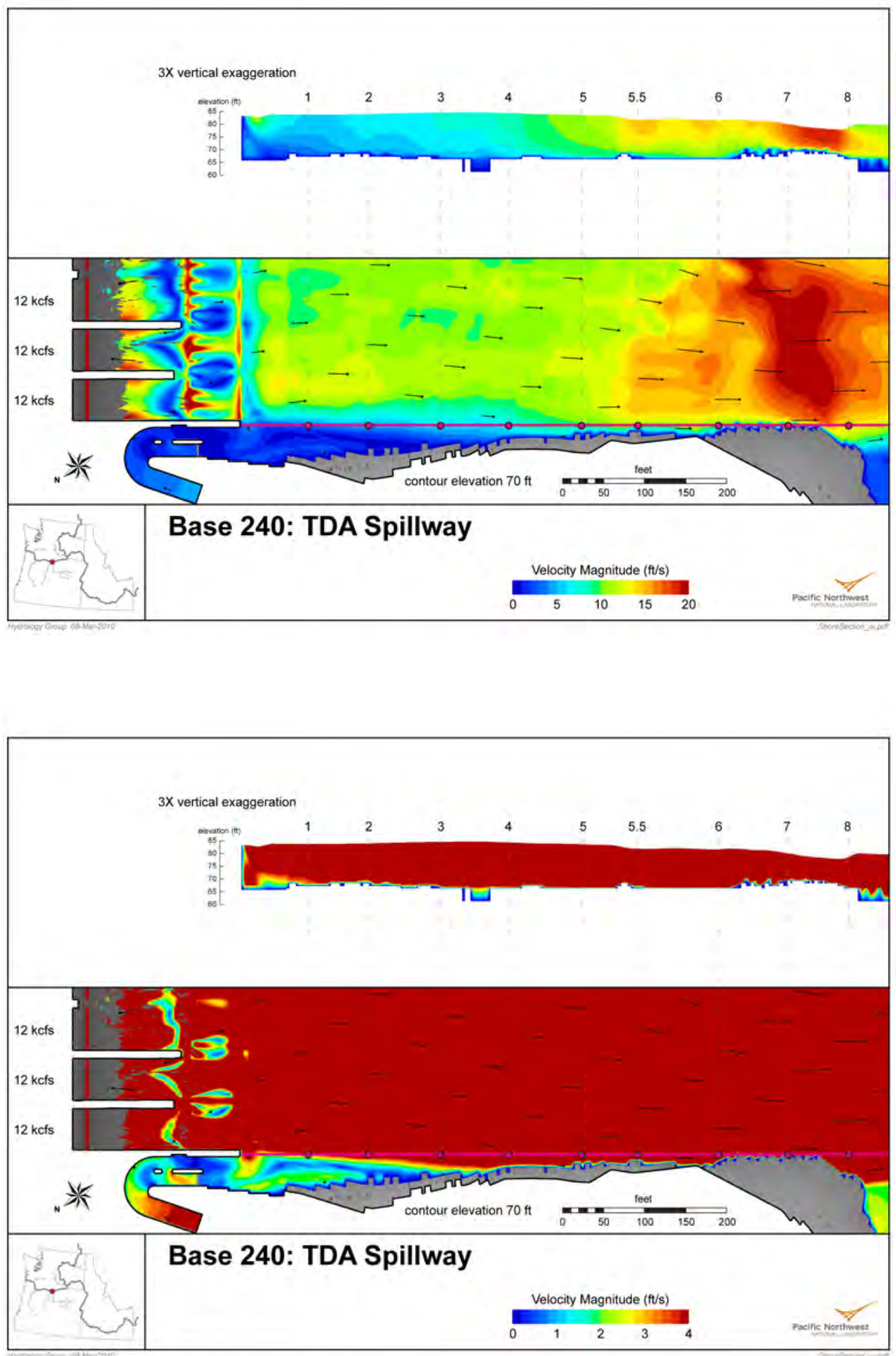

Figure 3.7. Simulated velocities near the Washington shore for $240 \mathrm{kcfs}$ Total River, $40 \%$ spill at elevation $70 \mathrm{ft}$. The lower figure shows areas with velocities greater $4 \mathrm{ft} / \mathrm{s}$ (a velocity believed to exclude predators) in red. 

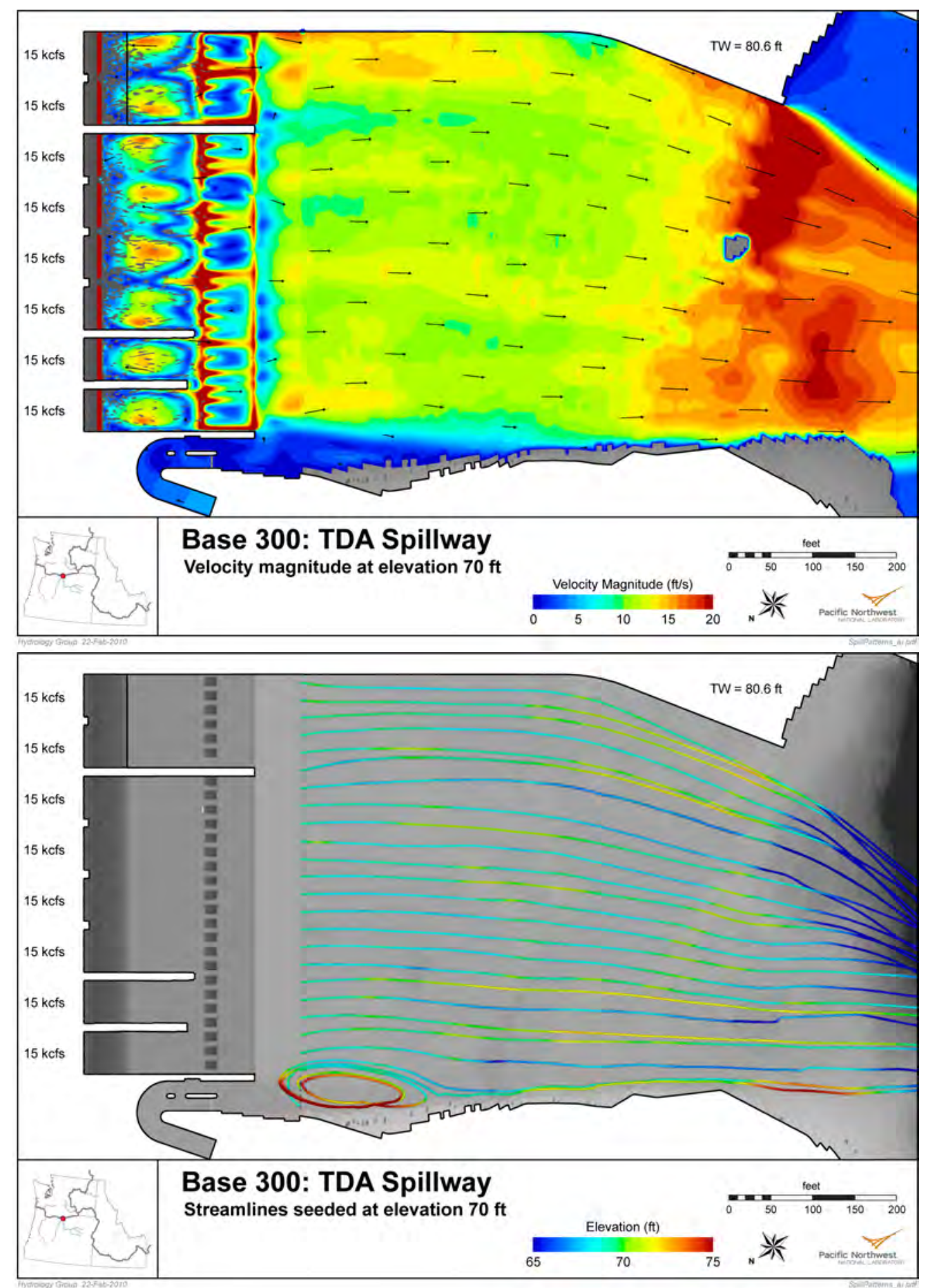

Figure 3.8. Simulation results between the spillwall and the Washington shore for $300 \mathrm{kcfs}$ Total River, $40 \%$ spill. The upper figure shows velocities at an elevation of 70 ft. The lower figure shows streamlines, colored by elevation, for particles seeded downstream of the stilling basin. 

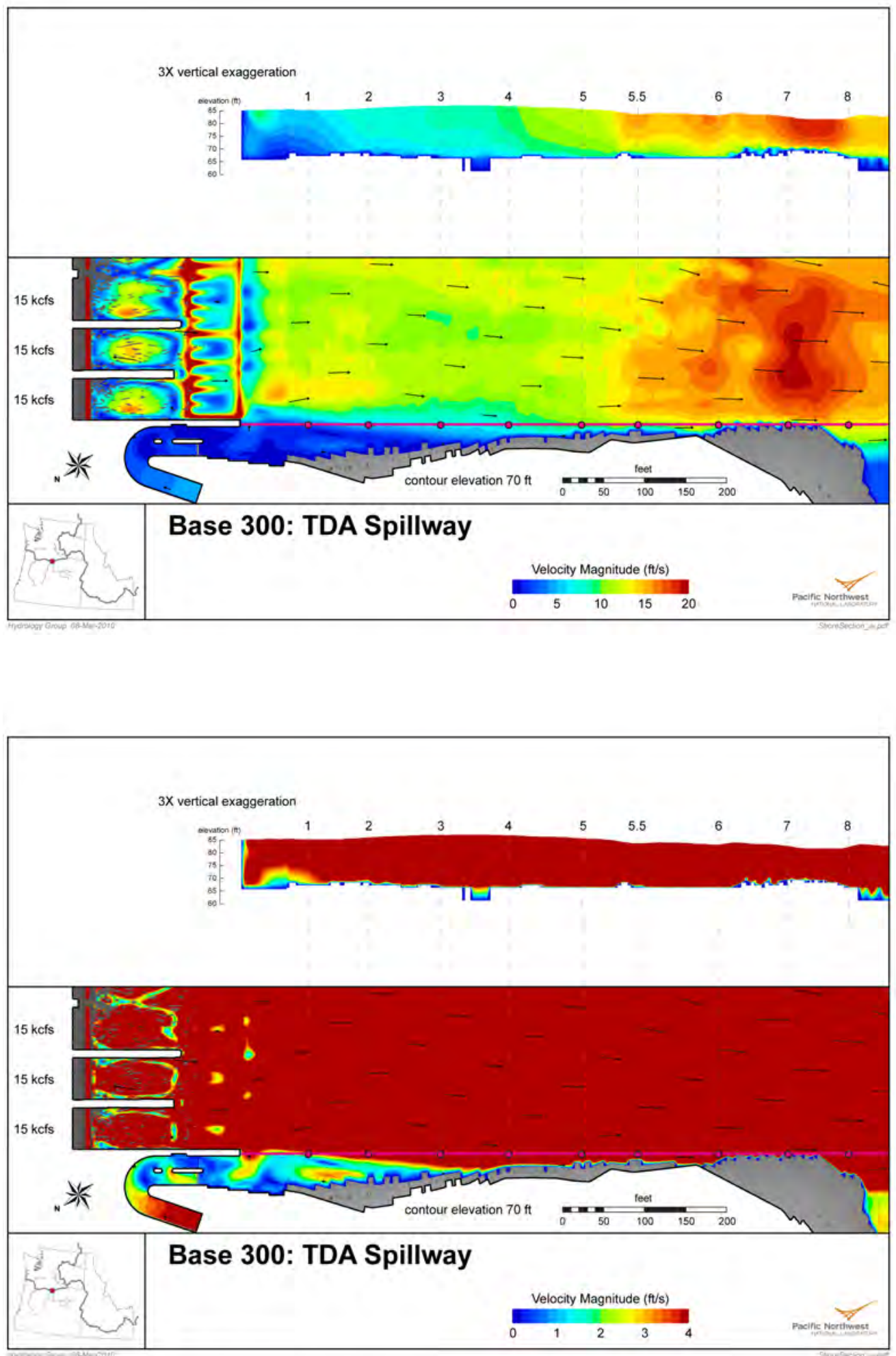

Figure 3.9. Simulated velocities near the Washington shore for $300 \mathrm{kcfs}$ Total River, $40 \%$ spill at elevation $70 \mathrm{ft}$. The lower figure shows areas with velocities greater $4 \mathrm{ft} / \mathrm{s}$ (a velocity believed to exclude predators) in red. 

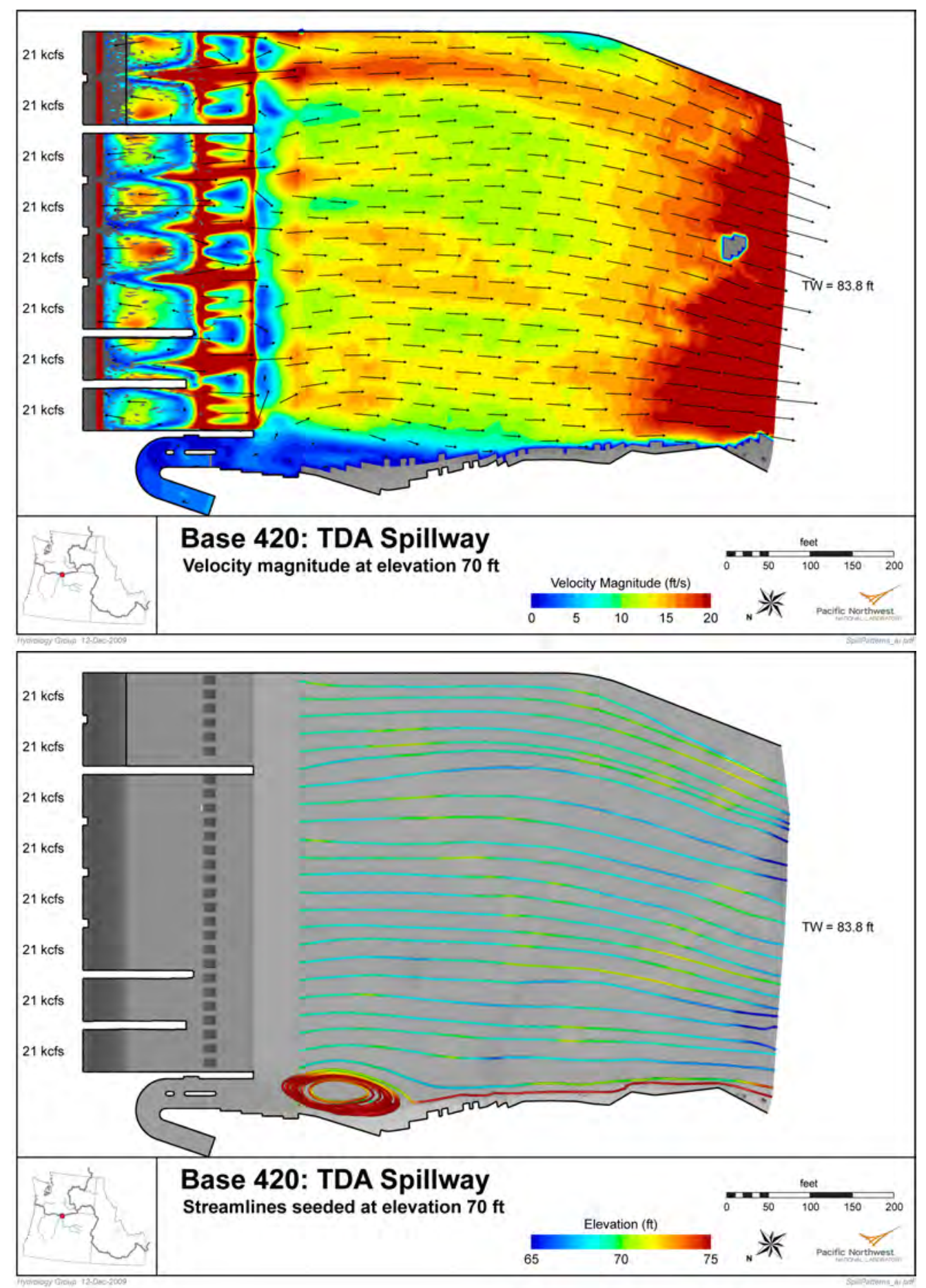

Figure 3.10. Simulation results between the spillwall and the Washington shore for $420 \mathrm{kcfs}$ Total River, $40 \%$ spill. The upper figure shows velocities at an elevation of 70 ft. The lower figure shows streamlines, colored by elevation, for particles seeded downstream of the stilling basin. 

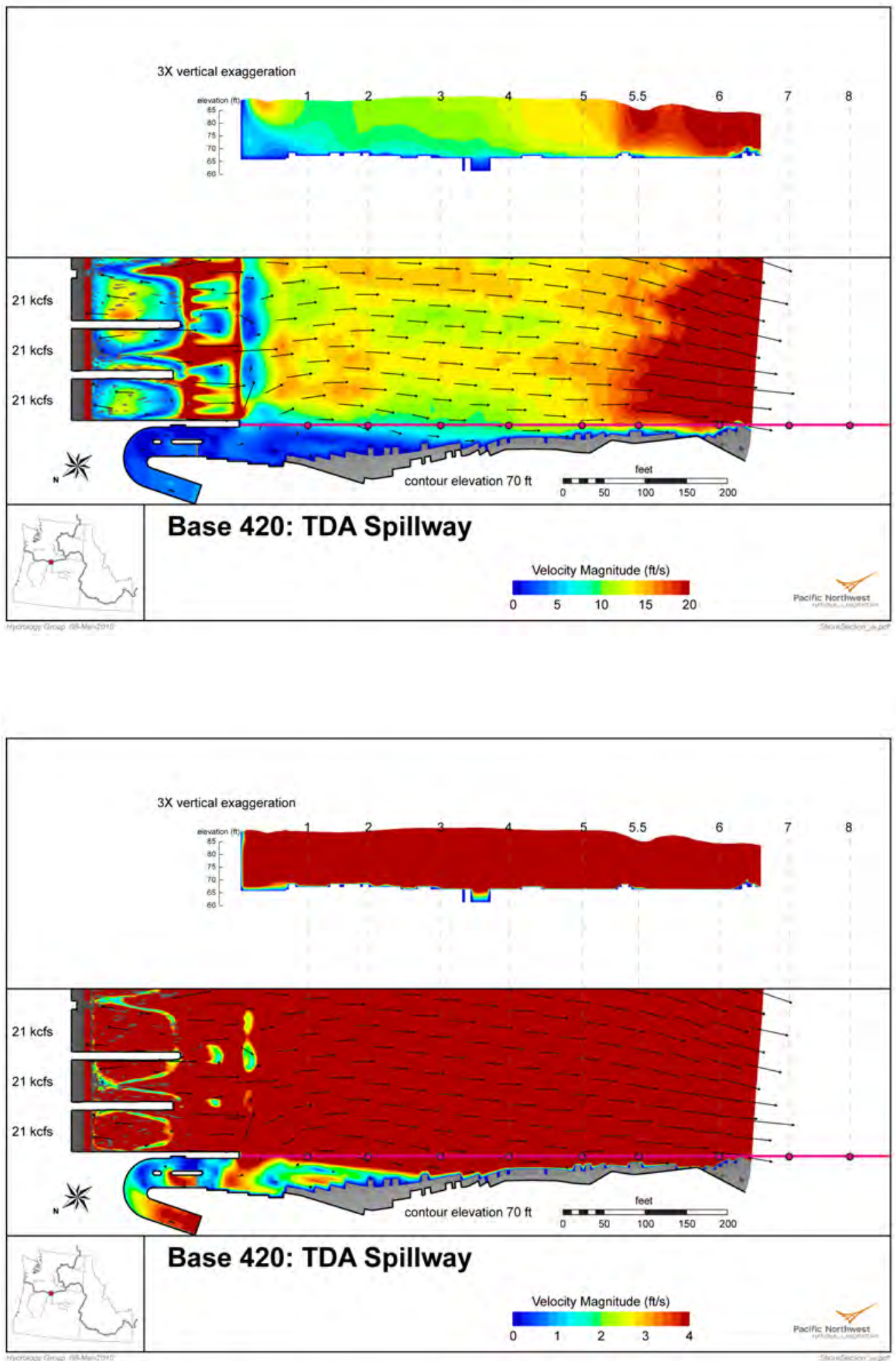

Figure 3.11. Simulated velocities near the Washington shore for $420 \mathrm{kcfs}$ Total River, $40 \%$ spill at elevation $70 \mathrm{ft}$. The lower figure shows areas with velocities greater $4 \mathrm{ft} / \mathrm{s}$ (a velocity believed to exclude predators) in red. 

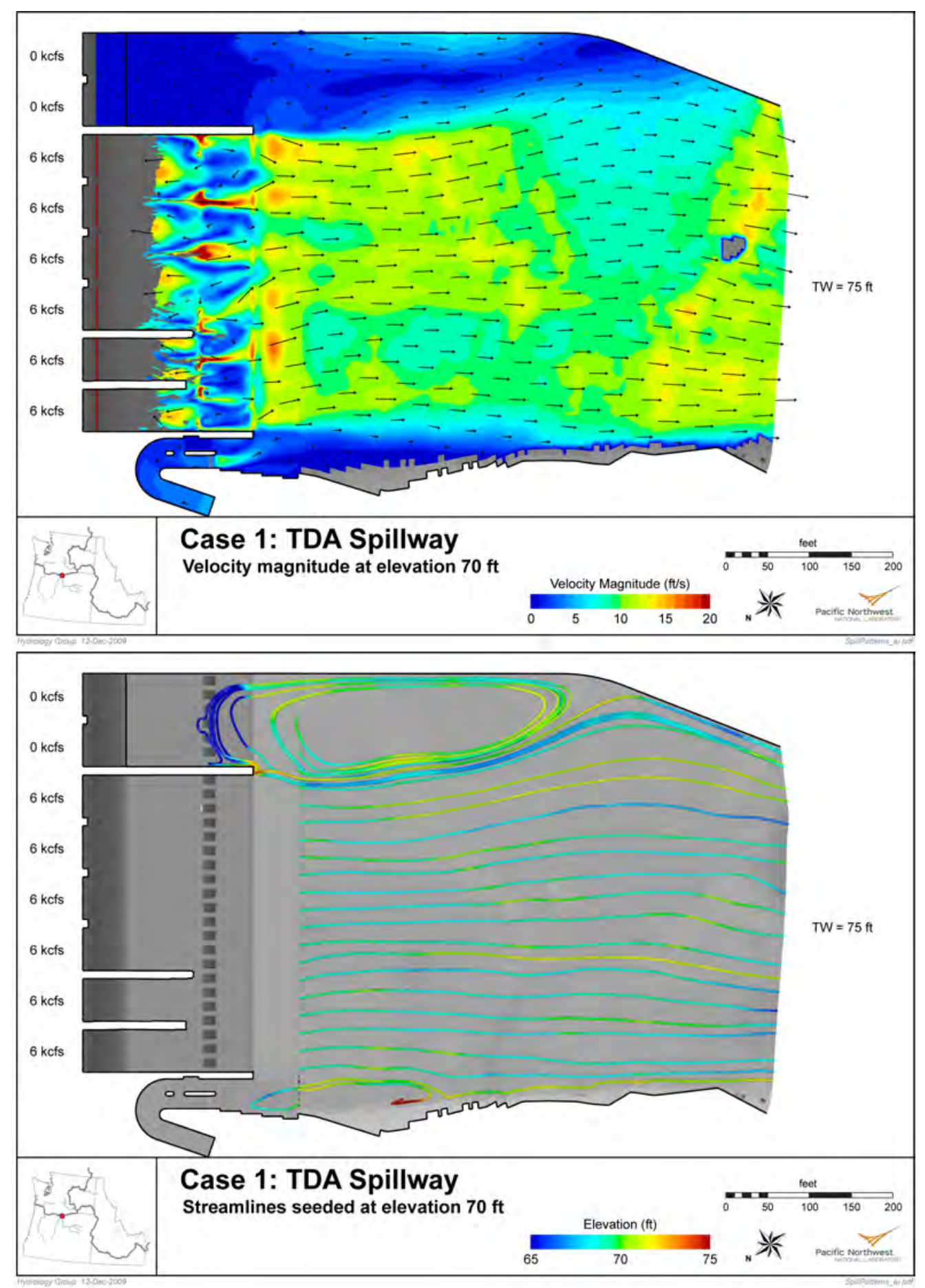

Figure 3.12. Simulation results between the spillwall and the Washington shore for $90 \mathrm{kcfs}$ Total River, $40 \%$ spill (Bays 1-6 at $6 \mathrm{kcfs}$ ). The upper figure shows velocities at an elevation of $70 \mathrm{ft}$. The lower figure shows streamlines, colored by elevation, for particles seeded downstream of the stilling basin. 

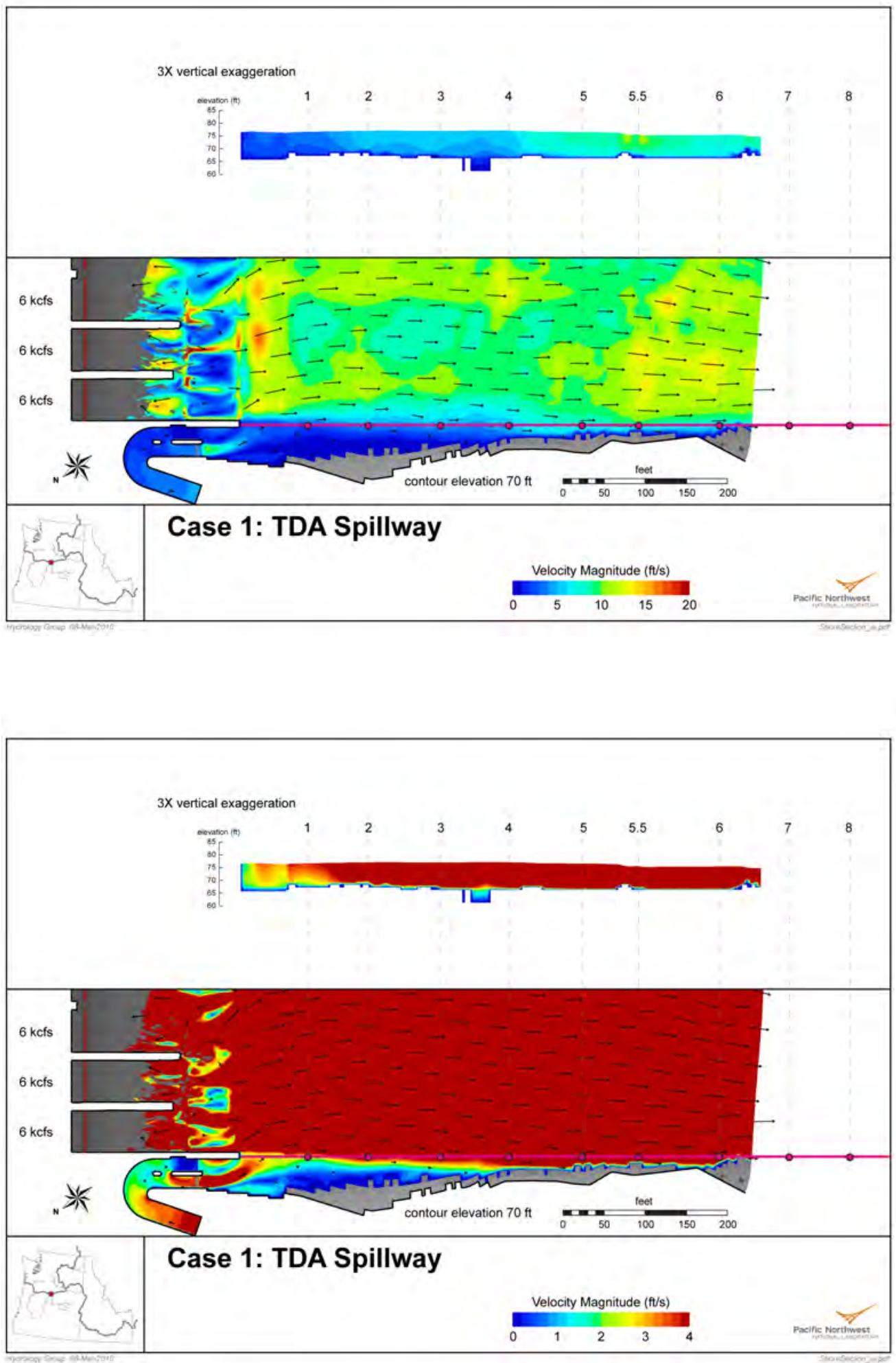

Figure 3.13. Simulated velocities near the Washington shore for $90 \mathrm{kcfs}$ Total River $40 \%$ spill (Bays 1-6 at $6 \mathrm{kcfs}$ ), at elevation $70 \mathrm{ft}$. The lower figure shows areas with velocities greater $4 \mathrm{ft} / \mathrm{s}$ (a velocity believed to exclude predators) in red. 

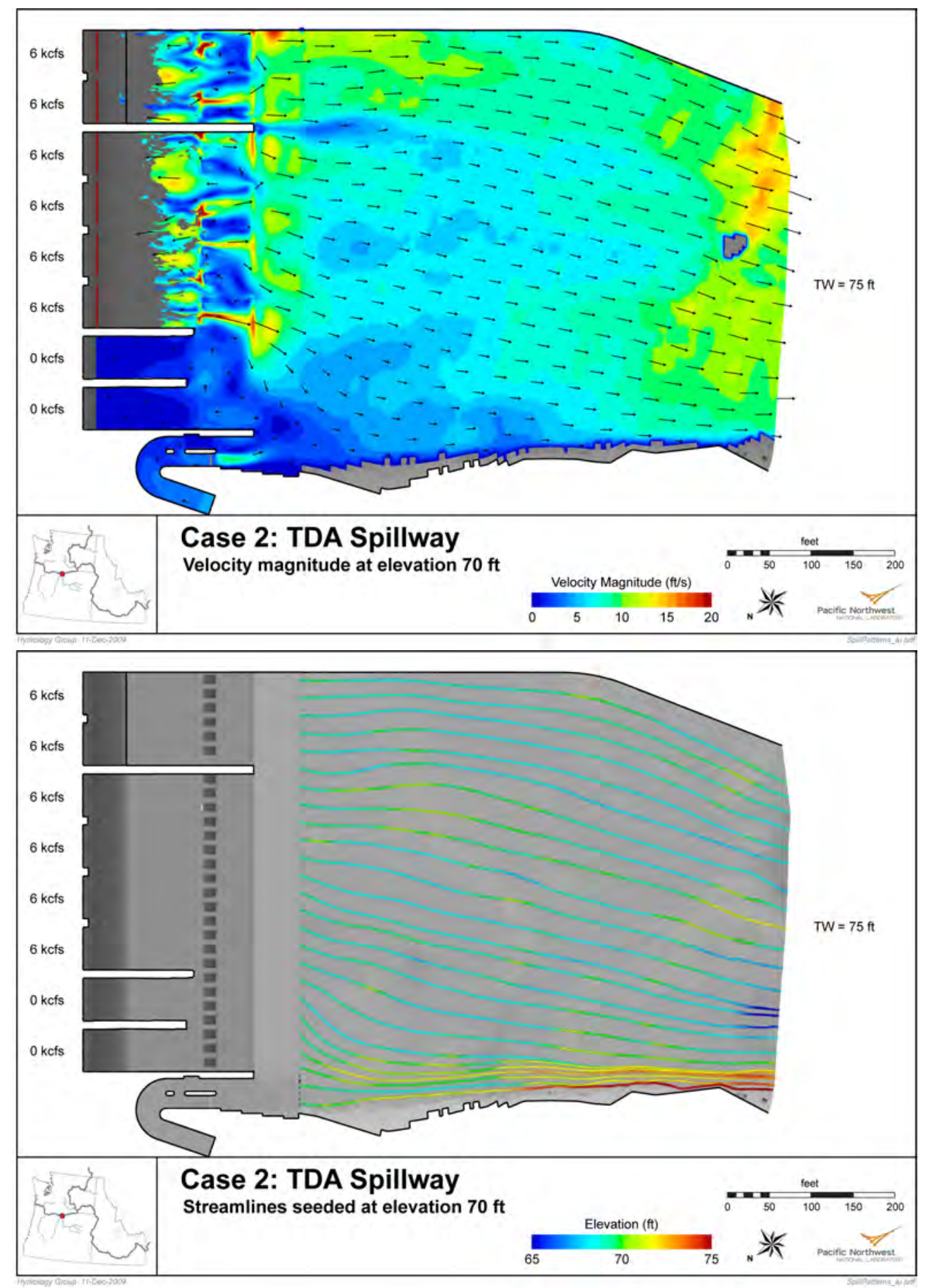

Figure 3.14. Simulation results between the spillwall and the Washington shore for $90 \mathrm{kcfs}$ Total River, $40 \%$ spill (Bays 3-8 at $6 \mathrm{kcfs}$ ). The upper figure shows velocities at an elevation of $70 \mathrm{ft}$. The lower figure shows streamlines, colored by elevation, for particles seeded downstream of the stilling basin. 

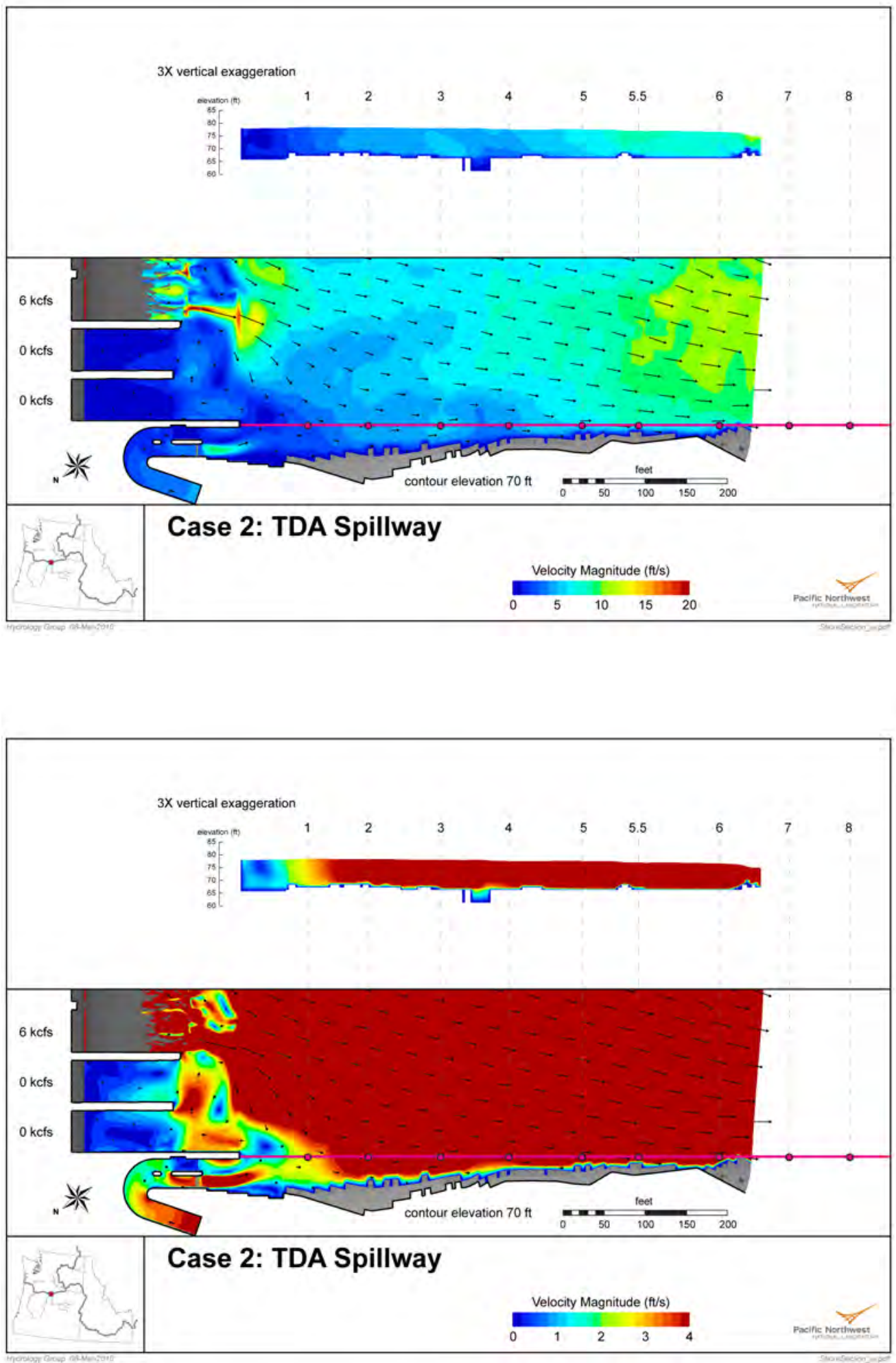

Figure 3.15. Simulated velocities near the Washington shore for $90 \mathrm{kcfs}$ Total River $40 \%$ spill (Bays 3-8 at $6 \mathrm{kcfs}$ ), at elevation $70 \mathrm{ft}$. The lower figure shows areas with velocities greater $4 \mathrm{ft} / \mathrm{s}$ (a velocity believed to exclude predators) in red. 

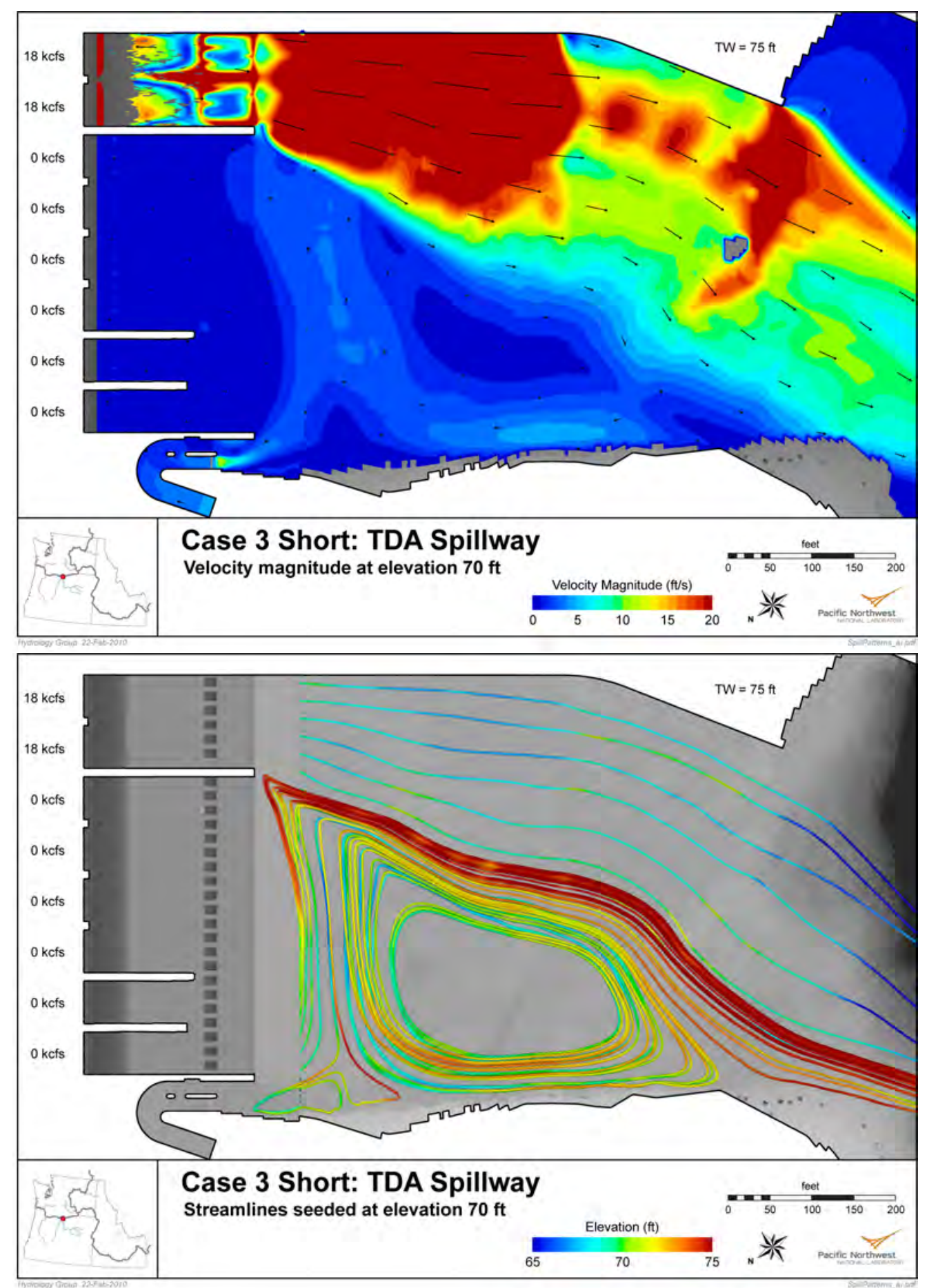

Figure 3.16. Simulation results between near the Washington shore for $90 \mathrm{kcfs}$ Total River, $40 \%$ spill (Bays 7 and 8 at $18 \mathrm{kcfs}$ ), at elevation $70 \mathrm{ft}$. The lower figure shows streamlines, colored by elevation, seeded outside the stilling basin. 

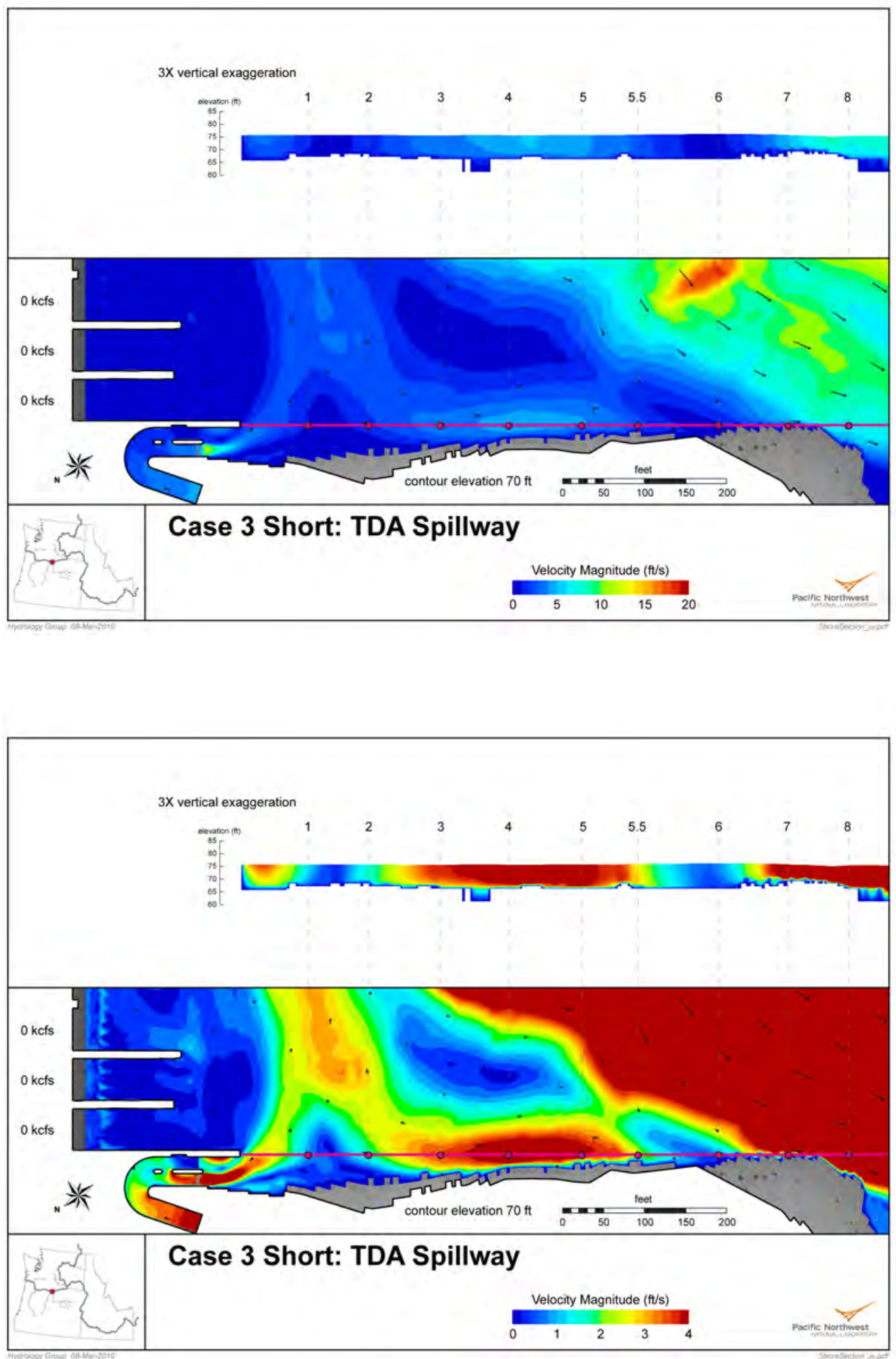

Figure 3.17. Simulated velocities near the Washington shore for $90 \mathrm{kcfs}$ Total River $40 \%$ spill (Bays 7 and 8 at $18 \mathrm{kcfs}$ ), at elevation $70 \mathrm{ft}$. The lower figure shows areas with velocities greater $4 \mathrm{ft} / \mathrm{s}$ (a velocity believed to exclude predators) in red. 



\subsection{Conclusions}

This study used a CFD model to characterize tailrace hydraulics between the new spillwall and the Washington shore for six different total river flows. The effect of spillway flow distribution was simulated for three spill patterns at the lowest total river flow.

The model results were used in two ways. First, results graphics were provided to CENWP and regional fisheries agency representatives for use and comparison to the same flow conditions at the ERDC reduced-scale physical model. The results graphics were very similar in flow pattern to that produced by the reduced-scale physical model but these graphics provided a quantitative view of velocity distribution. During the physical model work, an additional spill pattern was tested. Subsequently, that spill pattern was simulated in the numerical model.

The streamlines showed that the hydraulic conditions were beneficial to egress at the higher total river flows (120 kcfs and greater, uniform flow distribution). At the lowest flow case, $90 \mathrm{kcfs}$, it was necessary to use a non-uniform distribution. Of the three distributions tested, splitting the flow evenly between Bay 7 and Bay 8 was deemed most beneficial for egress by CENWP fisheries biologists and regional fishery agency representatives. The numerical and physical model results were very similar, building confidence in both hydraulic tools. 



\subsection{References}

CD-adapco, Computational Dynamics Limited. 2009. CCM User Guide, STAR-CD Version 4.08. CD-adapco, http://www.cd-adapco.com.

Rakowski C, W Perkins, M Richmond, and J Serkowski. 2008. Simulation of The Dalles Dam Proposed Full Length Spillwall. PNNL-17322, Pacific Northwest National Laboratory. Memorandum for Record to the U.S. Army Corps of Engineers Portland, Oregon. 



\section{Appendix A}

\section{Additional Graphics}





\section{Appendix A - Additional Graphics}

The iso-velocity plots (Figures A.1 to A.6) are included here for completeness. These show that the downstream constriction of the spillwall is sufficient to create velocities that are sufficient to exclude predators from this zone for all but one case. For the $90 \mathrm{kcfs}$ Case 3 with flows in Bays 7 and 8 (Figure A.6), there was a narrow band near the shore with modeled velocities less that 4 $\mathrm{ft} / \mathrm{s}$. However, much of the reason for doing this spill pattern was to reduce the velocities along the Washington shore to improve access to the North fish ladder by returning adult salmon. 

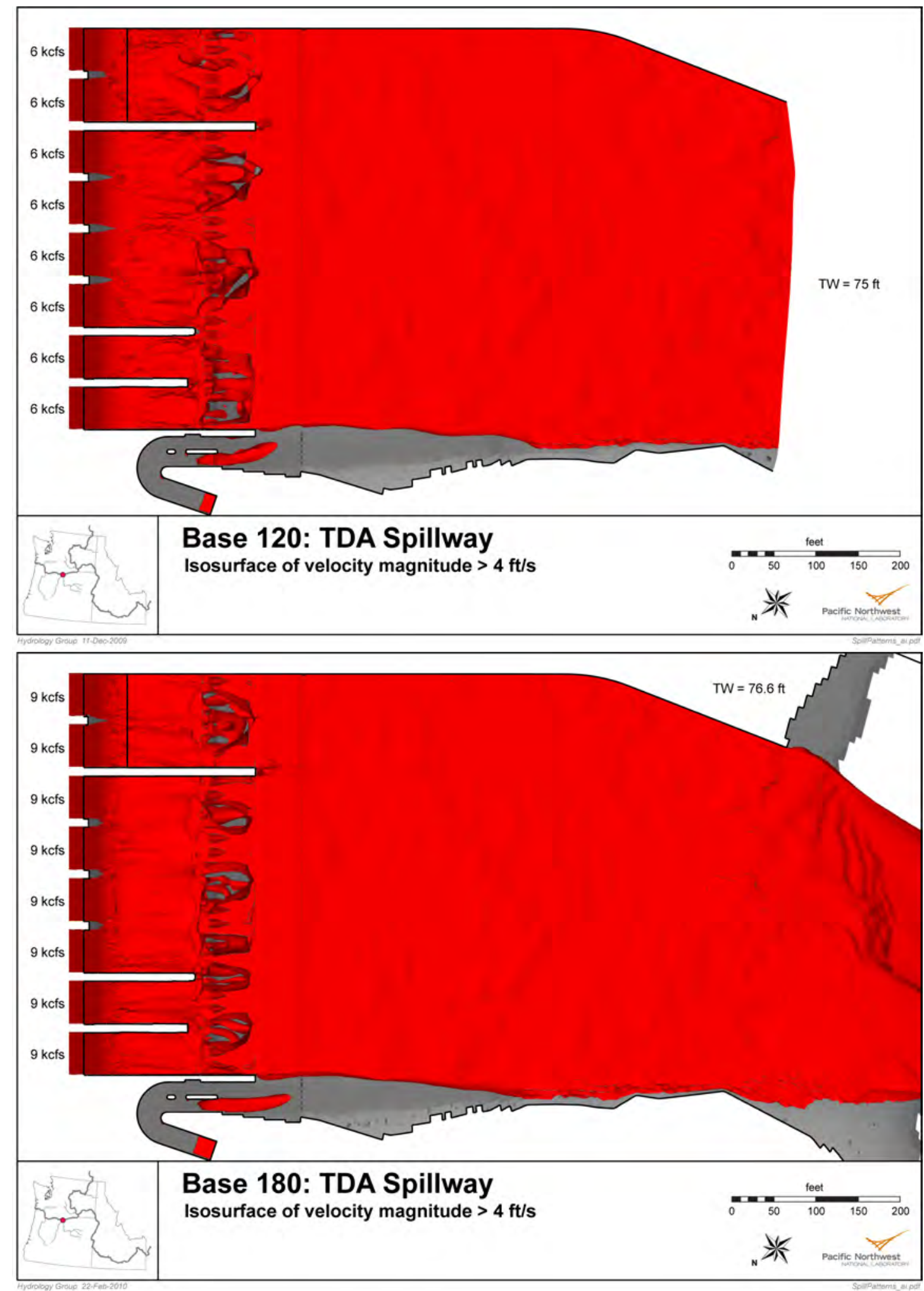

Figure A.1. Iso-velocity surface for a velocity of $4 \mathrm{ft} / \mathrm{s}$ for lower flows. The upper figure shows 120 kcfs Total River. The lower figure shows 180 kcfs Total River. 

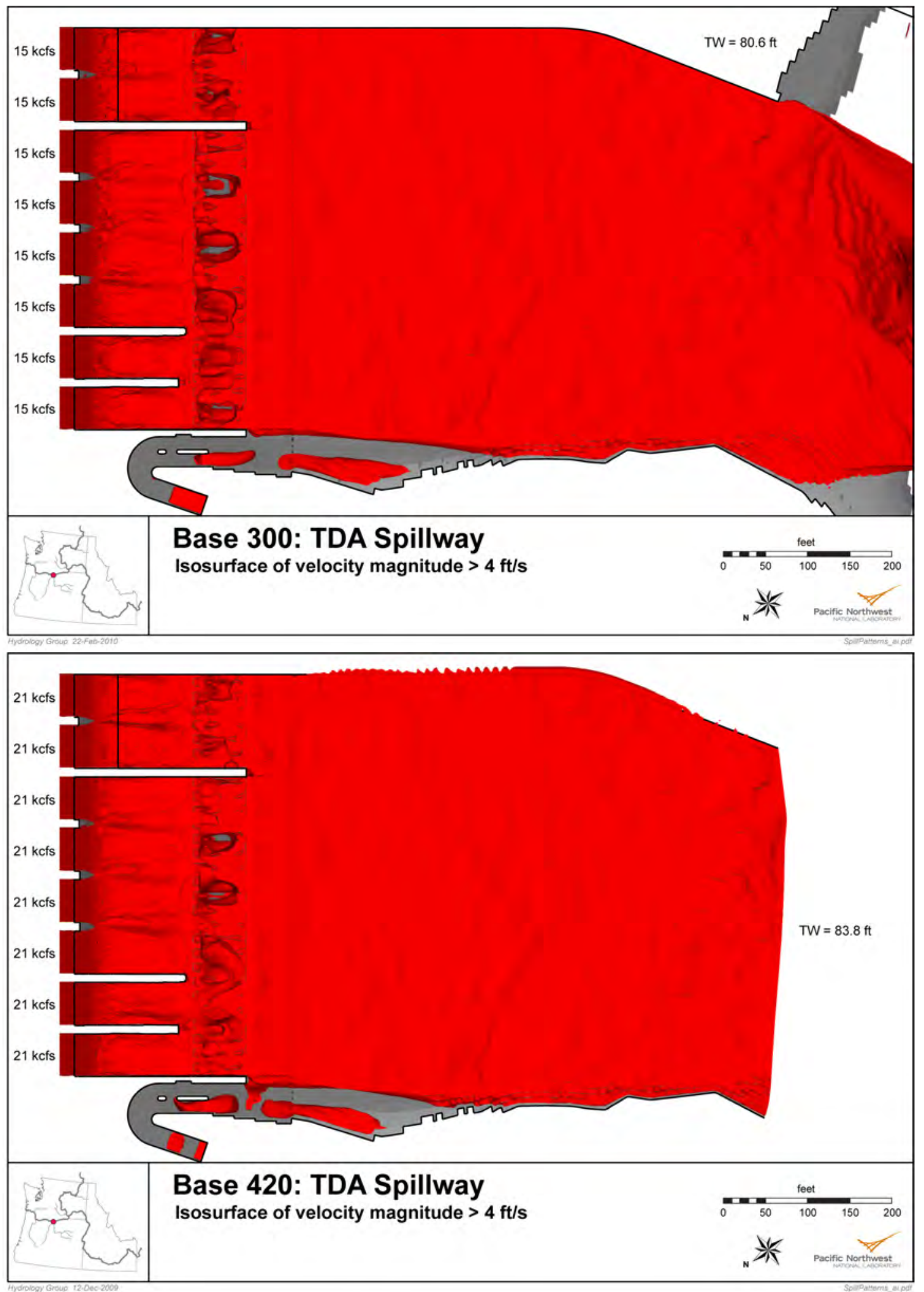

Figure A.2. Iso-velocity surface for a velocity of $4 \mathrm{ft} / \mathrm{s}$ for higher flows. The upper figure shows 300 kcfs Total River. The lower figure shows 420 kcfs Total River. 

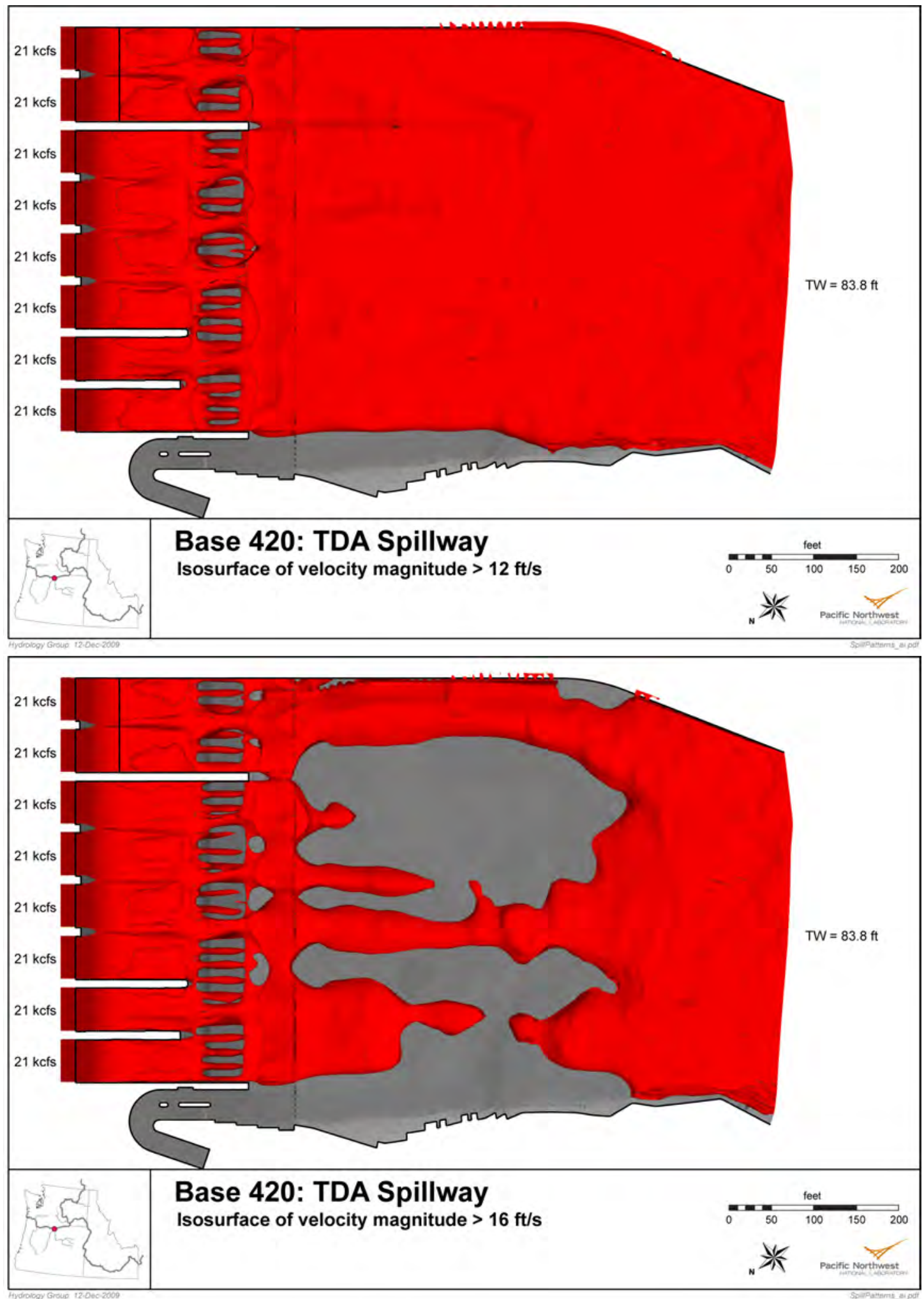

Figure A.3. Iso-velocity surface for a velocity of 12 and $16 \mathrm{ft} / \mathrm{s}$ for $420 \mathrm{kcfs}$ Total River. 


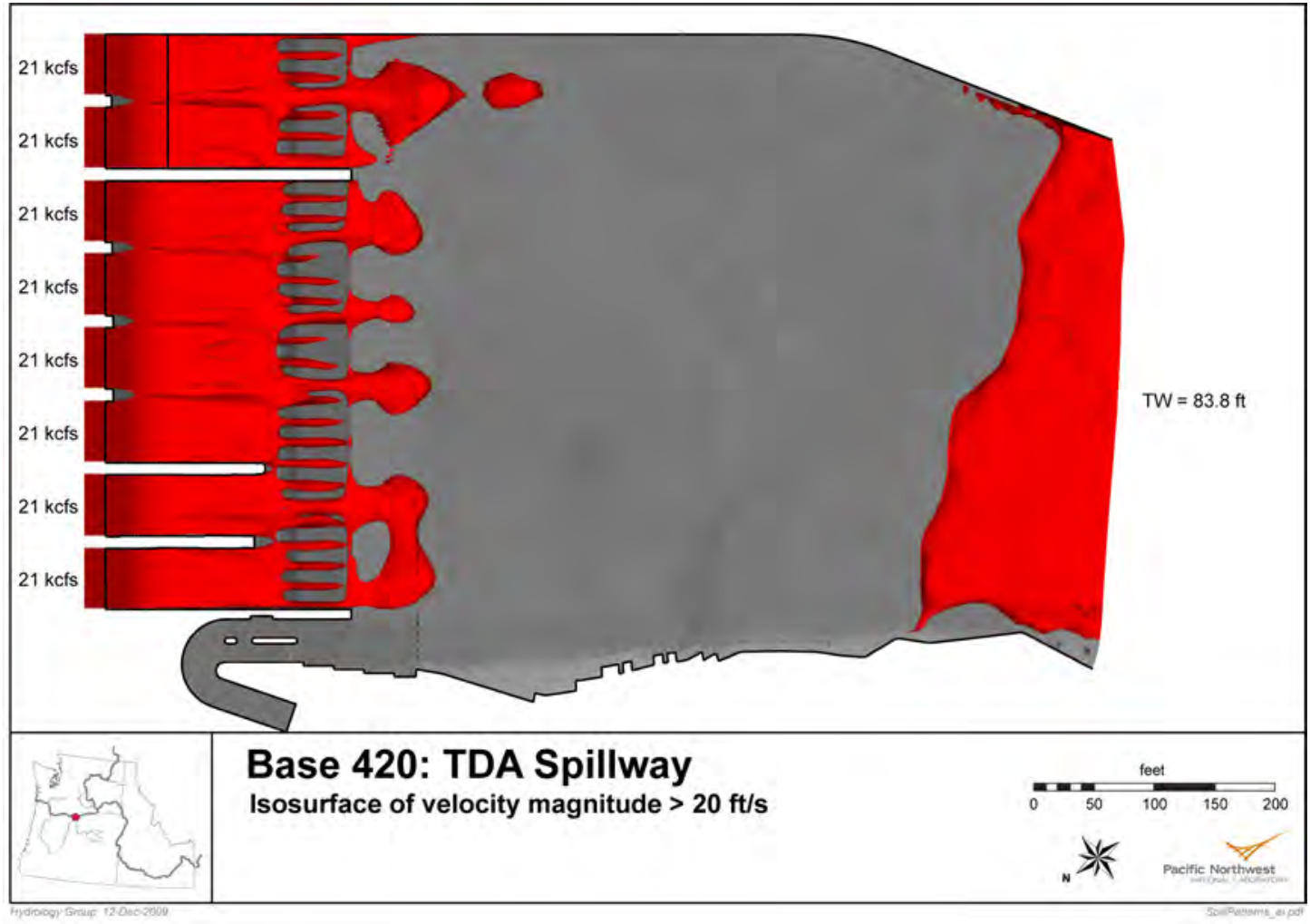

Figure A.4. Iso-velocity surface for a velocity of $20 \mathrm{ft} / \mathrm{s}$ for $420 \mathrm{kcf}$ Total Rivers. 

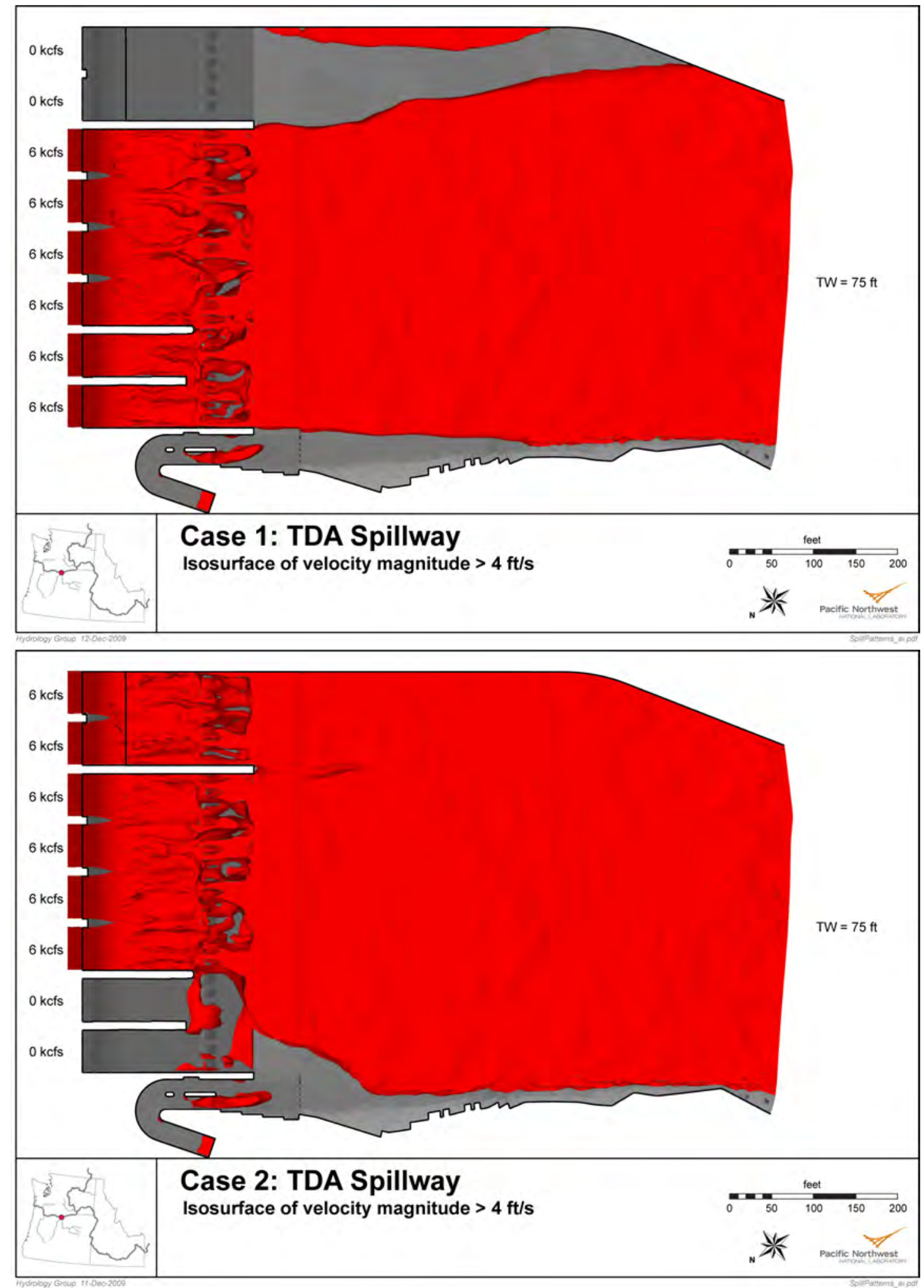

Figure A.5. Iso-velocity surface for a velocity of $4 \mathrm{ft} / \mathrm{s}$ for $90 \mathrm{kcfs}$ Total River for Cases 1 and 2. The upper figure shows spill flows in Bays 1 to 6 . The lower figure shows spill flows in Bays 3 to 8. 


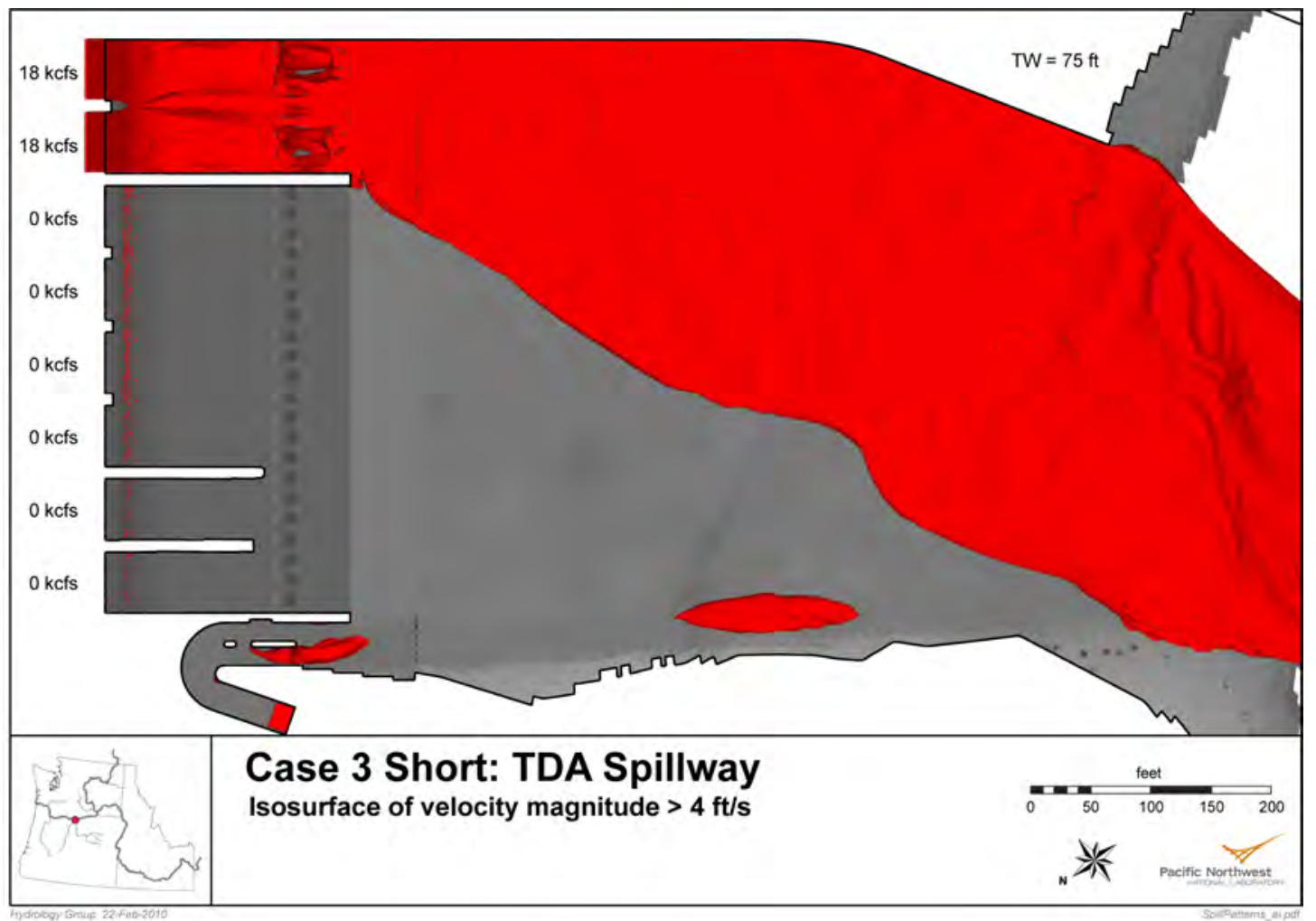

Figure A.6. Iso-velocity surface for a velocity of $4 \mathrm{ft} / \mathrm{s}$ for $90 \mathrm{kcfs}$ Total River for Case 3 with spill flow in Bays 7 and 8. 




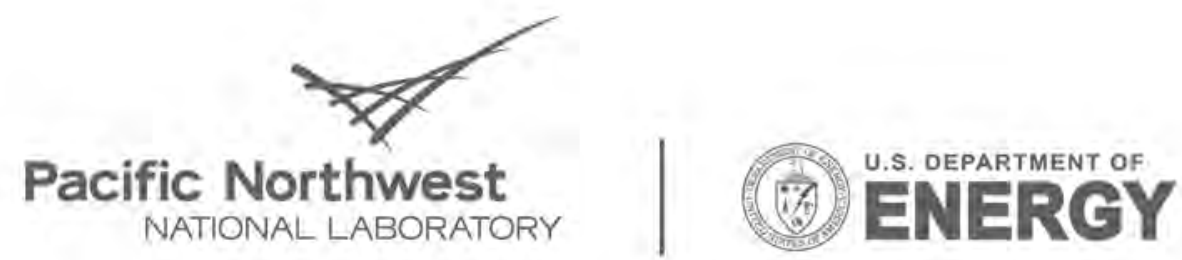

Proudly Operated by Battelle Since 1965

902 Battelle Boulevard

P.O. Box 999

Richland, WA 99352

1-888-375-PNNL (7665)

www.pnl.gov 